\title{
Uluslararası Kalkınma Politikaları ve Kadınların Güçlendirilmesi Üzerine Bir Değerlendirme
}

\author{
Fatma YILDIRIM ${ }^{1}$ ve Hasan GÜL ${ }^{2}$
}

$\ddot{O} z$

Gücün farklı tanımları olduğu gibi görünür ve görünmez birçok biçiminden de söz etmek mümkündür. Bunun sebebi gücün; bireyler tarafından farklı şekillerde tanımlanmış ve zaman içinde toplumsal düzene de yansımış olmasıdır. $\mathrm{Bu}$ bağlamda dünya düzeni açısından 'güç'; öncelikle ekonomik veya siyasi büyüme algisı ile özdeş kıllınmış gerek ulusal gerekse uluslararası boyutta tüm politika ve uygulamalar bu mevcut alg1 üzerinden düzenlenmiştir. Küreselleşmeyle beraber yaygın olarak kullanılmaya başlayan 'kalkınma' kavramının da başta ekonomik ilerleme olmak üzere, batıllıaşma, modernleşme gibi ifadelerle aynı manada kullanılması; güç kavramı ile özdeş tutulmasına zemin hazırlamış, ekonomik olarak bağımsız olan tarafin güçlü olduğu görüşü de çoğunlukla kabul görmüştür. Bütün bunlarla beraber var olan patriarkal ideolojinin de etkisiyle gerek uluslararası gerek Türkiye'de yapılan 'kadın ve kalkınma' konulu çalışmalarda, düzenlemelerde ve uygulamalarda kadınların ekonomik bağımsızlıklarını kazanmalarına ve önündeki engellerin kaldırlmasına öncelik verilse de bu düzen içinde kadınlar, iktisadi bir aktör olarak değil büyük ölçüde siyasi ve sosyo-politik sorunlarının çözülmesinde bir unsur olarak görülmüştür.

Anabtar Kelimeler: Kalkınmada kadınlar, Toplumsal cinsiyet, Kadınların güçlendirilmesi

\section{An Evaluation on International Development Policies and Women Empowerment}

\begin{abstract}
There are different definitions of power, and it is possible to mention visible and invisible forms of it. The reason is that it has been defined in different ways by individuals and it has been reflected in the social order over time. In this context, in terms of world order, power was primarily equated with economic or political growth, and all of the politics and practices, both in national and international scale, have been arranged based on the perception available. The fact that the concept 'development', which is widely used along with globalization, is used to refer to the expressions such as economic development, westernization and modernization paved the way to regard it equal to the concept of power, and the belief that those countries which are economically powerful are stronger has become the norm. Together with all these, under the influence of the existing patriarchal ideology, in the studies, arrangements and practices about 'women and development' done both internationally and in Turkey, the economic freedom of women and removing all sorts of obstacles which hinder this freedom have been prioritized, however, women, in this system, have been regarded not as economic actors but, to a large extent, as an element to solve political and socio-political problems.
\end{abstract}

Key Words: Women in development, Gender, Women empowerment

Atıf İçin / Please Cite As:

Yıldırım, F. ve Gül, H. (2021). Uluslararası kalkınma politikaları ve kadınların güçlendirilmesi üzerine bir değerlendirme. Manas Sosyal Araştırmalar Dergisi, 10(1), 679-695.

Geliş Tarihi / Received Date: 07.02.2020

Kabul Tarihi / Accepted Date: 24.09.2020

\footnotetext{
${ }^{1}$ Doktora Öğrencisi - Ondokuz Mayıs Üniversitesi, Lisansüstü Eğitim Enstitüsü, yazan.fatmayildirim@gmail.com

(iD) ORCID: 0000-0002-3585-5370

2 Prof. Dr. - Ondokuz Mayıs Üniversitesi, İktisadi ve İdari Bilimler Fakültesi, İşletme Bölümü, hasan.gul@omu.edu.tr

(iD ORCID: 0000-0002-3720-5451
} 


\section{Giriş}

Kalkınma; çok değişim gösteren, dinamik, çok yönlü hatta taraflı bir kavramdır. Kalkınma tanımlandığında ilk olarak ekonomik kalkınma akla gelse de artık günümüzde ülkelerin kalkınmış sayılması için sadece ekonomik kalkınmanın yeterli olmadığı sosyal, siyasal ve insani kalkınmanın da aynı oranda gerçekleşmiş olması gerekliliğine dikkat çekilmektedir. Bu açıdan kalkınma, hem kavram hem politik olarak karmaşık bir süreçtir.

1990 yılı İnsani Gelişme Raporunda; kalkınmanın belli amaç ve araçları olduğu, bunlar arasında da bir ayrım yapılmasının zorunlu olduğu bildirilmiş̧ir. Ayrıca kalkınmanın nihai amacının insanların başarıları, özgürlükleri ve yapabilirlikleri üzerine temellendirilmesi gerektiği vurgulanmıştır. Çünkü sadece gelir odaklı anlayışı yeterli görmeyen insani gelişme yaklaşımı, kalkınmanın merkezine insanı koymaktadır. (Gürses, 2009, s. 339). Insan faktörü yani beşerî sermaye günümüzde hızla değişen dünyanın en önemli üretim faktörüdür (Yenilmez ve Umut, 2008, s. 157). Zamanla beșerî sermaye ve kalkınma arasındaki ilişki netleştikçe de tüm dünyada kalkınma süreci yeni bir bakış açısı kazanmıştır.

En önemli faktörü insan olan kalkınma kavramını tartısırken yine aynı dönemde kadınların toplumsal kalkınma sürecine nasıl ve ne şekilde dâhil olduğu veya edildiği önemli bir konudur. Cinsiyet eşitliği ve kadınların güçlendirilmesi, sürdürülebilir olan yeni modeller ve süreçler oluşturmada daha bütünsel bir strateji olarak görülmüştür. Genel itibariyle toplumsal cinsiyet; insanları kadın ve erkek olarak ayırmaksızın, sahip oldukları veya sahip olması gereken haklarının katı cinsiyet rollerine bağlı kalmaksızın kullanılabilmesi ve firsatlardan yararlanabilmesi özgürlügüne sahip olma anlayışıdır. Kadınların güçlendirilmesi ise aslında hem süreç hem sonuçtur ki Dünya Bankası kadınların güçlendirilmesini tüm programların kilidi olarak tanımlamıştır. Ancak toplumsal cinsiyete dayalı bilinç tam olarak oturmadan; kadınların güçlendirilmesi için politikalar uygulanmaya konulmuştur. Bu programlar da öncelikle ekonomik kalkınmaya odaklandığından; kadınların uzun yıllar boyunca daha zor şartlarda, emek yoğun işlerde çalısmalarına dolayısıyla maddi ve manevi açıdan güçlerini kaybetmelerine zemin hazırlanmışıı. $\mathrm{Bu}$ noktadan hareketle uluslararası kalkınma politikalarında kadınların güçlendirilmesi adına yapılan çalışmaların sonuçları, toplumsal cinsiyet eşitliği açısından tartışmalara konu olmuştur.

Bu çalışmada, uluslararası kalkınma politikalarında toplumsal cinsiyetin ana akım politikalarına katılmasıyla beraber kadınların güçlendirilmesi için yapılan uygulamalar tarihsel bir perspektifte açıklanacaktır. Bunun için önce dinamik bir kavram olan kalkınma ve kadınların güçlendirilmesi kavramları tanımlanacak, daha sonra başta Birleşmiş Milletler (BM) olmak üzere uluslararası kalkınma politikalarında toplumsal cinsiyetin ve kadınların güçlendirilmesi ilişkileri yorumlanacaktır. Ayrıca uluslararası kalkınma politikaları içindeki Kalkınmada Kadınlar Yaklaşımı (WID), Kalkınma ve Kadınlar Yaklaşımı (WAD), Kadınlarla Kalkınma Alternatifleri Yaklaşımı (DAWN) yaklaşımları uluslararası kalkınma politikaları sürecinde ardışı kurgu içinde ele alınacaktır. Böylece kalkınma planları içinde yapılan uygulamaların ve yaklaşımların nasıl etkileşime girdiği tarihsel olarak değerlendirilecektir.

\section{Kalkınma Kavramının Yolculuğu ve Kadınlar}

Kalkınmanın zaman içinde birçok farklı tanımından söz etmek mümkündür. 1930'lardan itibaren daha çok kullanılmaya başlayan kalkınma kavramı; önceleri ekonomik ilerleme ile özdeşleştirilmiş, batılılışma ve modernleşmeyle eş kabul edilmişsir. Bu paradigmalara bağlı olarak bu dönemlerde bir ülkenin kalkınması teknolojik gelişmişlik seviyesi, ulusal gelir artış1, diğer ekonomik göstergelerle doğru orantılı olduğu ileri sürülmüş, böylece kalkınmayı da sayıların en iyi yansıttığı tartışmasız kabul edilmiştir. 1970’li yıllara gelindiğinde ekonomik olarak büyüme sergileyen, diğer bir ifadeyle sayısal göstergelerinde bir sorun olmayan bazı ülkelerde siyasal istikrarsızlık ve artan isssizlik gibi eșitsizlik temeline dayalı problemler ortaya çıtı̆ı̆1 görülmüştür. 1980'lerde küreselleşmenin ve neoklasik iktisat politikalarının temelinde şekillenen Uluslararası Para Fonu (IMF) ve Dünya Bankası'nın (WB) gözetiminde yapısal uyum politikaları süreci başlamıştır. Bu programların hareket noktası ekonomide her yönlü liberilazasyonun gerekli ve elzem olduğudur. Programın temel hareket noktası, üretimin iç tüketimden ihracata kaydırılması fikridir (T.C. Başbakanlık KSSGM, 2000, s. 4). Böylelikle, bu programı uygulayan devletlerin küçülmeleri için öncelikle uluslararası anlaşmalarla ve özelleştirmelerle ekonomik büyüme yakalanmaya çalışılmıştır (Onaran, 2000, s. 194). Ancak ekonomik istikrarın sağlanması aşamasında iç talebi kısıtlayıcı politikaların da etkisiyle en başta emek piyasasında birtakım çarpıklıklar yaşanmış; bu durum başta kadınlar olmak üzere toplumların çoğunu yoksulluğa, işsizliğe maruz bırakmış, kırdan kente göçe ve sigortasız çalışma şartlarını kabule mecbur bırakmıştır. Bilhassa ihracat sektöründe düşük ücretli emek kullanılması, işgücü piyasasında kadın çalısanların sayısını gözle görülür seviyede artırmıştır (T.C. Başbakanlık KSSGM, 2000, s. 7). İşgücünün 
kadınlaşması olarak da tanımlanan bu süreçte dünya genelinde gelir eşitsizliği, işsizlik gibi ciddi sorunlar meydana gelmiş; kalkınma için ekonomik büyümenin tek başına çözüm getirmediği fikirleri ortaya atılmıştır. Büyüyen tartışmalar neticesinde kalkınmanın; insanların yaşam koşullarına bağlı büyüme, yenilenme, değişim gibi kavramları içinde barındırdığı hususunda geniş bir fikir birliğine varılmışıır (Şenses, 2004, s. 1-2).

Kalkınma kavramının kendi içindeki evrimi uzunca bir süre devam etse de bu süreçlere kadınların dâhil edilmesi yıllarca ihmal edilmiştir. Kalkınma içinde kadınların üretici rolünün gerekli olması ve kadınların istihdama katılarak özellikle üçüncü dünya ülkelerinde yoksulluğun önlenebileceği düşüncesi; kadınların kalkınmaya dâhil edilmesinin iki önemli nedeni olarak karşımıza çıkmaktadır (Özar, 2012, s. 300). Ayrıca aynı dönem toplumsal cinsiyete dayalı güç ilişkilerinin sorgulanması, toplumsal yap1 ve sistemlerinin değişmesi gerekliliğini gündeme getirdiğinden kalkınma alanında kadınların güçlendirilmesi ve toplumsal cinsiyet eşitliği konularına ilişkin duyarlılık da artmıştır. Böylece daha önce toplumsal hareketlere özgü olan güçlendirme kavrami; 1980’lerde yeni liberal ekonomi politikalarının olumsuz etkilerini azaltmaya çalışan kalkınma bürolarına dâhil olmaya başlamıştır (Parpart, 2014, s. 383-384). Ancak kadınların güçlendirilmesi için kadınlarla ilgili özel politika, proje, planlar yapılmamış, bunun yerine kadınlar kalkınma süreçlerine tamamlayıcı bir unsur olarak dâhil edilmiştir. Diğer bir ifadeyle kadınlar, kalkınmanın diğer amaçları için araç gibi düşünülmüsstür (Toksöz, 2011, s. 50).

$\mathrm{Bu}$ süreçte biyolojik cinsiyetin ötesinde; kadın veya erkek gibi davranmayı temel alan, toplumsal etkileşimden, değerlerden, kültürden kaynaklı hem dinamik hem de değişken bir kavram olan toplumsal cinsiyetin ana akım politikalara katılması yaklaşımı gündeme gelmiştir. Öncelikle 1985'te ilk kez Nairobi'deki Birleşmiş Milletler Kadın Konferansı'nda bir eylem çerçevesi olarak sunulmuş ardından 1995’te Pekin'deki Dördüncü Dünya Kadın Konferansında Birleşmiş Milletler üyesi devletler için resmi bir hedef olarak tanınmıştır. Bu konferans; küresel bir taahhüdü desteklemede büyük bir başlangıç olmuş, Pekin Deklarasyonu ve Eylem Planı kabul edilmiştir. 189 hükümet; toplumsal cinsiyet açısından önem arz eden çalışmaların etkili olabilmesinin kadınların katılımlarıyla mümkün olduğunu beyan etmiştir. Ayrıca kadınların güçlendirilmesinin, sürdürülebilir bir kalkınmanın temel şartı ve hatta gereklilik olduğunu vurgulamıştır (Komitesi Hak-İş, 2017, s. 25-27). Bunlara ek olarak bu konferansa katılan hükümetler, kadınların siyasi temsilciliklerine de dikkat çekmiş, kota uygulamasını vaat etmişlerdir. Bunun neticesinde de bazı bölgelerde özellikle belediye seçimlerinde kayda değer artışlar görülmüştür (Kalayc1, 2019, s. 1088). Ancak yine de büyüyen ekonominin de etkisiyle faydalar ülkeler bazında eşit dağılmamış, derin ekonomik farklılıklara, toplumsal cinsiyet eşitsizliğinin artmasına, yoksulluğun kadınlaşmasına, enformel sektörün büyümesine sebep olmuştur.

Bu bağlamda toplumsal cinsiyet eşitliğinin ana akım politikalarında yer alması; farklı ülkelerde değişik görünümler sergilese de genel olarak bakıldığında toplumsal cinsiyet eşitliğine yönelik vurguların kadınların işgücüne katılımlarını sağlamaya ve onların emek piyasasında yaşadıkları eşitsizlikleri ortadan kaldırmaya yönelik olduğu görülmüştür. Fakat kadınları kurumsallaştırarak hükümetlerle birlikte programa dâhil edilen bu politikalar esasında kadınların çalısma ve aile yaşamlarını dengede tutmaları için düzenlemeler içermektedir fakat amaç; emek piyasasındaki esnek emeğin önünü açmak ve ona daha kolay ulaşabilmektir (Walby, 2005, s. 20). Ayrıca hem gelişmiş hem de gelişmekte olan ülkelerde çalışan kadınların birçok farklı sorunla başa çıkmak zorunda kaldığı, kariyerlerindeki engel ve problemlerin de çoğunlukla benzer nitelikte olduğu belirgindir (Gül ve Beyşenova, 2018, s. 140). Kadın emeği, bir toplumun iç dinamikleri harekete geçirmesinin etken bir unsuru olduğundan; kalkınma diye nitelendirilen gelişmeler emek yoğun işlerde kadının iş yükünü ve sorunlarını daha da artırmıs, erkeğin otoritesini hatta yetki alanını daha da genişletmiş̧tir (Ertürk, 1996, s. 344).

Esasen kalkınmadan söz edilebilmesi için artışın geçici değil; devamlı, önemli ve reel olması lazımdır (Dulupçu, 1999, s. 155). Bu açıdan kalkınma; insan yaşamının siyasi, ekonomik, sosyal, kültürel ve diğer boyutlarındaki gelişiminin yanı sıra; insanın fiziksel, ahlaki, entelektüel ve kültürel gelişimini ve yansımalarını da içeren bir olgudur. Ayrıca kalkınma programları ve kalkınma planlamaları, ekonomik olduğu kadar sosyal ilerlemeyi de hızlandırdığı ölçüde başarılı kabul edilmelidir (İşler ve Şentürk, 2019, s. 380). Bu açıdan kalkınma süreçlerinde kadınlar ve toplumsal cinsiyet eşitliği konusu tüm toplumların gelişiminde esas kabul edilmelidir. Harris'e (2000) göre sosyal olarak sürdürülebilir ve kalkınmış bir sistem, ancak toplumda var olan kaynakların bireyler arasında eşit dağılımının sağlanmasıyla oluşmaktadır. Böyle bir sistem de sağlık olanaklanı, eğitimde firsat eşitliği, cinsiyet eşitlĭgi, politik sorumluluk gibi sosyal 
hizmetlerin yeterli düzeyde gerçekleştirilmesi ile mümkündür. Görülmektedir ki kalkınma; insani gelişme, eşitlik, sosyal adalet ve bireylerin kendilerini gerçekleştirmesi gibi üst esaslara dayanmaktadır.

\section{Kadınların Güçlendirilmesi}

Güçlendirme; yerel bir dilde açıklandığında sosyal, kültürel ve politik bağlamlarda farklı anlamlar taşısa da, ona bakış açısına göre farklı anlamları ifade eden tartışmalı bir kavram olsa da; kadın erkek ayırmaksızın insanların kendi hayatlarını kontrol altına alabilmeleri, kendi gündemlerini belirleyebilmeleri, beceri kazanabilmeleri ve karşılaştıkları problemleri çözebilmeleri demektir. Ayrıca yaşam kalitesi, insan saygınlığ1, insani büyüme ve gelişmiş hizmet sunumu için anahtar bir kavram, toplumun her kesiminden bireyin refahını sağlamak için temel bir strateji olarak kabul edilmektedir(UNWOMEN, 2010). Kanter, güçlendirmeyi "Men and Women of the Corporation" isimli eserinde "bir bireyin amaçlara ulaşmak için mevcut kaynaklardan yararlanma ve bağımsız şekilde kararlar alma yeteneği" olarak tanımlamıştır (Tolay vd., 2012, s. 451). Kadınlar için BM Kalkınma Fonu'na (UNIFEM) göre ise güçlendirme; 'bir bireyin tercih üretebilme, pazarlık gücünü kullanabilme ve bu beceriyi kazanabilme, öz-saygiyı geliştirebilme ve tüm bu değişimleri gerçekleştirebileceğine duyduğu inançtır'. Dolayısıyla güçlendirme karar alma, kararı uygulama, irade gösterme, tercih etme ve tabiî ki güçle alakalıdır (Balkız ve Öztürk, 2013, s. 8).

Tarihsel bir perspektiften bakıldığında kalkınma politikalarında kadınlar, 1970 yllına kadar gündeme getirilmemiştir. Hatta uygulama politikalarında kadınlara ilişkin raporlarda kadınlar; iktisadi aktör olarak değil bir nesne olarak görülmüş, onların sadece üretici yönüne dikkat çekilmiş ve buna yönelik çalışmalar yapılmıştır (Ertürk, 1996, s. 349). Güçlendirme; kalkınma, katılım, eşitlik, planlama ve yoksulluk gibi kalkınma çerçevesindeki kavramların içinde tartışıldığından (Sachs, 2010, s. 6) son dönemlerde kadınlara yönelik yapılan uluslararası uygulamalara ayrıca bir de 'güçlendirme' söylemi eklenmiştir. Böylece kadınların güçlenmesi ve güçlendirilmesi kavramları siyasi, ekonomik ve sosyal boyutlarıyla, uzmanların, siyasetçilerin ve karar alıcıların gündeminde sık sık yer almaya başlamıştır (Zihnioğlu, 2013, s. 2).

Kadınlarm güçlendirilmesi günümüzde, sadece toplumsal cinsiyet eşitliği açısından değil, sürdürülebilir kalkınma, ekonomik büyüme, siyaset, eğitim, barış ve güvenlik açısından irdelenen ve önem verilen bir gündem maddesi haline gelmiştir. Bu durum bazı feministleri güçlendirilme kavramını derinlemesine tartışmak ve cinsiyet perspektifini takip etmek için alternatif bir güçlendirme tanımı yapmaya itmiştir. Onlara göre güçlendirilme kavramı, gelişim içindeki kadınların yokluğuna tepki olarak ortaya çıkmış; onları farklı bir grup olarak soyutlamıştır. Çünkü kavram itibariyle güçlendirilme olması için bir başkasının, daha doğrusu güçlü bir aktörün karşı tarafa 'güç intikal' etmesi gerekmektedir. Bu da güçlendirilmenin ölçüm ve değerlendirilmesi aşamasında tartışmalara neden olmuştur.

Doğal olarak dünya genelinde her toplumun farklı kültürde olması, kadınların güçlendirilmesi hususundaki bu kavram belirsizliği ve alg1 yönetimi gerek bireysel idrak seviyesinde gerekse uluslararası politikaların uygulanmasında, gerek politik aktörler gerekse feministler arasında farklı tanımlamalara ve anlam farklılıklarına yol açmıştır. Örneğin Nelly Stromquist'e göre kadınların güçlendirilmesi öncelikle ekonomik olarak bağımsızlıklarını kazanmaları ile mümkündür. Ona göre yoksul kadınlar meşgul kadınlardır çünkü sadece aile ihtiyaçlarına cevap vermek için fazla zaman ve enerji harcamazlar, aynı zamanda katı otoriter eş kontrolü, evde şiddet, annelikle ilgili sosyal beklentiler ve fiziksel hareketliliklerini sınırlayan güvensiz topluluk ortamları gibi koşullarla da karşlaşmaktadırlar (Stromquist, 1955, s. 13). Jo Rowlands, kadınların güçlendirilmesi ile ilgili olarak "karar alma süreçlerine sadece erişimle sınırlı kalmamaları, yetkin ve yetenekli oldukları algisının da yaratılmasının gerekli olduğunun bilincine varılmasıdır" ifadesini kullanmıştır. Bireysel ve kolektif düzeyde değişim için bunun şart olduğu şeklinde ifadelerde bulunmuştur (Rowlands, 1997, s. 19-25).Naile Kabeer (1994) ise kadınların güçlendirilmesinin içten gelen bir olgu olduğunu savunmuştur. Toplum tarafından belirlenen normların, kadınlar ve erkekler için uygun davranışı belirlediğini, cinsiyetlendirilmiş kimliklerini geliştirilerek; insanların istedikleri hayatı yaşamalarından kiminle evleneceğine, çocuk sahibi olma isteğinden istediği işte çalışmaya kadar tüm kritik konularda yaşam tercihlerini yapması konusundaki özgürlüklerini sınırladıklarını söylemiştir. Dolayısıyla ona göre kadınların güçlendirilmesi, hayatlarını başka bir otoritenin çizdiği sınırlarla değil ancak kendi özgür iradelerini kullanmalarıyla mümkündür.

Genel olarak kadınların güçlendirilmesinde uluslararası politikalara bakıldığında, daha çok ekonomik bağımsızlıklarını kazanmaları ile benzer anlamda kullanıldığı görülmüştür. Ulusal ve uluslararası düzeyde yapılan politikalar kadınların ekonomiye katılımına öncelik vermiştir. Ekonomik özgürlügünü eline alan kadının kendisinden başlamak üzere etrafindakileri hatta toplumu olumlu yönde değiştirdiği inkâr edilmese de daha çok işgücü piyasasında yer alan kadın, 'güçlü' kadındır anlayışılla atılan her adım neo-liberal 
politikaların da etkisiyle kadınların hayatlarını kaçınılmaz biçimde daha da zorlaştırmışıı. Çünkü kadınların kendileri de buna dâhil olmak üzere, var olan ataerkil sistemdeki toplumsal cinsiyet rollerinin kendilerine dayattığı annelik, hasta bakıcıllğı, ev işleri gibi çalışmaları öncelikli kabul edip, işgücü piyasasında çalışma saatleri daha esnek işlerde yoğunlaşmışlardır. Bunun sonucunda da kadınlar sigortasız, sendikasız ve güvencesiz işlerde yığılma göstermiştir. Ayrıca bu kanıksanmış sistem içinde kadınlar kendilerini ispat etmek için daha çok gayret göstermiş, ayakta kalmak, başarmak adına yaptığı her hamle maddi ve manevi daha çok emek harcamalarına sebep olmuştur.

\section{Tarihsel Süreçte Uluslararası Kalkınma Politikaları ve Kadınların Konumu}

Kadınların uluslararası süreçte kalkınma politikalarındaki konumu; toplumsal cinsiyet eşitliği anlayışı ve kadınların güçlendirilmesi kavramlarının da ortaya çıkmasıyla karmaşık hale gelmiş, tarihsel perspektif içinde de çeşitlilik göstermiştir. 1929'da kalkınma ile ilgili girişimlerin hemen hepsinde kadınlar göz ardı edilirken; modernleşme kalkınmanın teknik üstünlüklerine bağlı kılınmıştır. 1940’larda kalkınma planlayıcıları tüm dünyayı modernize etmeyi amaçlayan projeler şekillendirseler de İkinci Dünya Savaş1 sonrası Amerika Birleşik Devletleri hegemonik bir güç olarak ortaya çıkmıştır. Daha sonra 1946'da BM Kadının Statüsü Komisyonu kurulmuştur. Ancak bu komisyonun cinsiyet farklılaşması açısından çalışmaları yeterli düzeyde olmamıştır. Dolayısıyla bu dönemlerde kadın haklarına ilişkin konularda çalışmaların hemen hepsi insan hakları içinde değerlendirilmiş, toplumsal cinsiyet eşitliği konusunda bir farkındalık yaratılamamıştır (Yavuz ve Serdaroğlu, 2010, s.50).1952 yılında ise tüm kadınlar için iş gücünde ve anne çocuk için sağlık ve güvenilirliği daha ileri noktalara taşımak için, devletlerarasındaki farklılıkların olduğu bir dünyada iş yerleri arasındaki farklılıkları da gidermek adına ILO örgütünün genel konferansında Annelik Koruması Sözleşmesi sunulmuş ve şartları üye devletler tarafından kabul edilmiştir. Bu sözleşmede, işyerlerinde annelerin ve anne sağllğının daha iyi hale getirilmesine yönelik hükümetlerin üzerine düşen rollerin önemine değinilmektedir. Ek olarak anneliğin ve kadınların üreme rollerinin ekonomik güvenliklerini tehdit etmemesi gerektiğine vurgu yapılmakta ve gerekli önlemlerin alınması amaçlanmaktadır (Makal, 2001, s. 118).

Bu dönemlerde kadınlarla ilgili politikaların temelinde annelik, çocuk sağlığı, nüfus planlaması, hamilelik gibi kadınların yeniden üretimdeki rollerine odaklanılmıstır. Kadınlara, kalkınma programlarında kadın olarak değil de eş ve anne olarak yer verilmiştir. Neoklasik yaklaşımda kadınlar hane içinde, doğal kabul edileni yani ev işini ve çocuk bakımını üstlenmekte; piyasa ekonomisine katılmadığından üretici olmayan aktör konumuna sokulmuşlardır. Böylece kadınlar, tüm dünyanın sımsıkı sarıldığı kalkınma hikâyesinin içinde görünmeden ve sesleri duyulmadan adeta bir gölge gibi yer almışlardır. Çünkü ekonomik büyümeyle birlikte toplumların refah düzeyleri artarsa doğru orantılı olarak kadınların da durumlarının iyileşeceği düşünülmüştür. Ayrıca diğer bir anlayış da toplumların modernleştikçe, kadınlar üzerindeki baskılar azalacağı, eğitim ve istihdam firsatlarının da çoğalacağı var sayılmıştır (Toksöz, 2011, s.48-49).

8 Mart 1857'de Amerika'da bir grup kadın işçinin 'eşit işe eşit ücret' ve 'çalısma saatlerinin kısaltılması' için iş yaşamlarında insani talepleri olduğu için işten atılması sonucunda 129 kadın hayatını kaybetmiştir. Daha sonra Dünya Kadınlar Günü olarak tarihe geçen bugün aslında kadınların cinsiyetçi ayrımların ötesinde bir birey olarak var olma isteklerinin, sadece annelik ve üreme modeliyle sinırlandırılmak istemediklerinin de bir bildirgesi olmuştur. 1960’larda kalkınma ajanslarının erkeklerin elinde olmasının etkisiyle, kadının çalışma hayatından ziyade gerçek yerinin evi olduğu anlayışından hareketle anne-çocuk sağlığı programlarına ağırlık verilmiştir. Kadınların yeniden üretimdeki rolleri irdelenerek; kadınların ülke içindeki refah payları sorgulanmaya başlanmıştır. Fakat kadınların statüleri arttıkça doğurganlıklarının azalmasının fark edilmesiyle; toplumsal ve iktisadi koşulların belirlendiği yeni açılımlar gündeme getirilmiştir.

Dolayısıyla 1960’ların sonlarına doğru kadınların kalkınma programları içinde sadece bir araç olarak kullanılması hatta asıl odağının annelik rolü olarak algılanması ve algılatılması; bazı feministlerin dikkatini çekmiştir. Bu süre içinde kadınların birey olarak kapitalizm içindeki ezildiğini, ücretli emek alanlarından dışlandığını, yeniden üretim sorumluluklarıyla sınırlandırıldığını savunmuşlardır. Karl Marks'ın fikirlerinin feminizme uyarlanmış hali olarak bu dönemde ortaya çıkan Marksist feminizm ile birlikte kadınların ev dışına çıkmaları, ücretli işçiler olmalarını ve kamusal alana katılarak özgürleşebileceği konuları gündeme getirilmiştir. Bu açıdan bu dönem ulusal ve uluslararası tüm kalkınma çalşsmaların toplumsal cinsiyet eşitliği açısından ihmallerle dolu olduğunu fark ettirmesi açısından önemlidir (Karaçay vd., 2014, s. 20). 
1970'de Danimarkalı bir araştırmacı olan Ester Boserup'ın “Woman's Role in Economic Development" isimli eseri hem kalkınma hem de toplumsal cinsiyet açısından bir dönüm noktası olmuştur. Bu kitap, cinsiyetçi iş bölümü ve kalkınmanın modernize edilmesini kavram olarak ifade etmese de toplumsal cinsiyet üzerindeki etkisini verilere ve kanıtlara dayandırarak inceleyen ilk çalısma olması sebebiyle önem arz etmektedir. Bu kitapla ilk defa mevcut dönemdeki cinsiyetçi iş bölümü küresel düzeyde betimlenmiştir (Rathgeber, 1989, s.3). Boserup bu kitabında işgücü piyasasında yer alan kadınların yaptıkları işlerin ülkeden ülkeye hatta bölgeden bölgeye dahi dikkate değer şekilde farklılık gösterdiğinivurgulamıştır. Toplumlarda çoğunlukla erkeklerin para kazandırıcı rolünün genelleştiğine, kadınların ise hep aynı işleri yaparak istihdam olanaklarının kısıtlandığını vurgulamış, kalkınma projelerinin Üçüncü Dünya ülkeleri kadınları üzerindeki etkisine de değinmiştir. Diğer bir ifadeyle kalkınma projelerinin çoğunun kadınları göz ardı ettiğini, onların iktisadi çıarlarına ve bağımsızlığına sekte vurduğunu açıkça ifade etmiştir (Serdaroğlu, 2010, s. 129). Ayrıca modernleşmeyle birlikte tarımda ve diğer alanlarda verimlilik artışları yaşlandığını; teknoloji ve makine kullanımının bu süreçte erkeklerin kontrolüne geçmesiyle kadının ikincil konuma itildiği geleneksel iş bölümünün oluştuğunu göstermiştir. Bunun doğal sonucu olarak da toplum içinde verimli olabilecek kadın nüfus marjinalize edildiğinden, ekonomilerin bu insan kaynağının katkısından yoksun kalarak, ulaşabilecekleri refah düzeyinin gerisinde kalındığından bahsetmiştir. Bu bağlamda topyekûn bir kalkınma için kadınları ekonomiye dâhil edecek politikaların geliştirilmesine, onların ekonomik ve toplumsal konumlarını iyileştirecek politikalar üretmenin önemine 1srarla vurgu yapmıştır. Geçen bu zaman içinde çizilen bu çerçeve; gelişmiş ülkelerde ve pek çok uluslararası organizasyonlarda rağbet görmüş, bu da Kalkınmada Kadinlar Yaklassımı (WID) adını almıştır (Yücel, 2016, s.87).

Kalkınmada Kadınlar Yaklaşımı'nda; ekonomik kalkınma, sosyal kalkınmayı beraberinde getirildiğinden kadınlara yönelik bazı özel politikaların oluşturulması önerilmektedir (Hoşgör, 2011, s. 220). Uluslararası ajanslar tarafindan benimsenen bu yaklaşım modernleşme kuramı ile beslendiğinden; cinsiyet eşitliği tüm alanlara dâhil edilememiştir. Çünkü kadınlar, ayrı analiz edilmemekte; normların erkekler için geliştirildiğinde otomatik olarak kadınların da bunlardan yararlanacağı varsayılmaktadır. Ayrıca kadınların kalkınma programlarından ve stratejilerinden niçin daha az yararlandığının sebeplerini bulmak yerine, mevcut devam eden sisteme daha kolayca nasıl dâhil edilecekleri irdelenmektedir. Farklı bir ifadeyle, bu yaklaşımda kadınların neden ikincilleştirildiğinin, baskı gördüğünün doğası ve kaynakları sorgulanmamıştır. Yani kadınlar arasındaki sınıf, ırk ve kültürü göz ardı edilmiş, sömürüleri dikkate alınmadan sadece birtakım analizler yapılmıştır (Yavuz ve Serdaroğlu, 2010, s. 61-62). Bu dönemde bazı projelerde ve uygulamalarda kayda değer ölçüde neticeler elde edilse de kanunlar, politikalar, anlaşmalar cinsiyet merkezli olmadıklarından; kadınlanın her alanda yaşadığı eşitsizliklerin aynı şekilde devam ettiği daha da kötüsü kadınların ilave problemlerle, sıkıntılarla karşı karşıya kaldığ1 görülmektedir (Özyol, 2013, s. 135). Sadece eğitim aracıllğıyla kadının toplumsal konumundaki eşitsizliğin giderileceği öngörülmüss olup; yapısal değişikliklere ve üretim bağlantısına yeterince odaklanılmamıştır. Bu yıllarda da geçmiş ylllarda olduğu gibi ülkeler için uygulanan destekleyici kadın programları, ev ekonomisi, ana çocuk sağlığı, aile planlaması gibi projelerin de içinde olduğu sosyal refah politikaları kapsamımda irdelenmiştir. Buna göre kadınlar, domestik ve doğurganlık rolleriyle refahı gözetilmesi gereken kalkınma hedeflerinden birisi haline gelmiş; pasif alıcı şeklindeki bağımlılıkları bir kez daha vurgulanmıştır (Ertürk, 1996, s. 349). Bu süreçlerde kalkınma süreçleri içinde kadınlar ve cinsiyet eşitliği ile ilgili atılan adımların arkasındaki tek neden; kadınların ekonomik büyüme olgusu gibi görüldüğü gerçeğidir. Bütün bu etkileşimlerde kadınların güçlenerek özgürleşmesi ülkelerin kalkınma hedeflerinin amacı değil aracı haline gelmesi bazı feministlerin dikkatini çekmiş, hızla gelişen bu dünya düzeninde kadınların bireysel olarak var olmayışına bir tepkilerini ortaya koymalarına sebep olmuştur. Öncelikle kadın hareketine önemli bir kazanım sağlayan sosyalist feminizmin de etkisiyle kadınların kendi ayakları üzerlerinde durabilmeleri gerekliliği anlayışı ön plana çıkmıştır. Kadınların ev içinde, yani özel alanda, sıkışmışlı̆̆ına vurgu yapmış ve bu durağanlığa eleştiriler getirmiştir. Buna ek olarak 1974 yılında erkeklerin kadınlara ve tabiata karşı gösterdikleri agresif tavırlara tepki olarak ortaya çıan eko-feminist yaklaşım da yaşı, statüsü, 1 rkı, dini ne olursa olsun her kadının kendine özgü güzelliği ve kıymeti olduğunu savunmuştur. Onlara göre kadınların doğaya yakın olduğu algısı bilinçli olarak yaratılmış, doğayla beraber kadın da güçsüzleştirilmiştir. Kadın-erkek kavramı ile hiyerarşik bir ikilem oluşturularak kadın kamusal alandan uzaklaştırılarak hâkimiyet tek boyuta indirgenmeye çalışılmıştır (Özyol, 2013, s. 133-134). Bu açıdan kalkınma programları; yaşanan kadın sorunlarını, mevcut düzene direk olarak ekleyerek çözmeye çalıştı̆ından yeterli olmayacağı savunulmuştur. 
Bu dönemlerde kadınlar ve cinsiyet eşitliğiyle ilgili konular küreselleşmenin de etkisiyle; katılım, eșitlik, planlama ve yoksulluk gibi kalkınma çerçevesindeki kavramların içinde tartışılmaya başlanmıştır (Sachs, 2010, s. 7-8). Ayrıca kalkınmadaki temel amaç; fert başına milli gelirin artması olarak yorumlanmıştır (Sırma, 2006, s. 1). Daha açık bir tanımla öncesinde kalkınma, gelirlerdeki artışla doğru orantılı değerlendirilirken; sonrasında sadece ekonomik büyümenin değil, buna ek olarak yoksulluğun, işsizliğin, çalışma koşullarının ve gelir dengesizliklerin de değerlendirilmesiyle açıklanır olmuştur. Bu süreçlerde her alanda olduğu gibi cinsiyetler arasındaki eşitsizlikler de artmış ve dünyada toplumsal cinsiyet bakış açıları da gelişmiştir. Toplum tarafından kadınlara ve erkeklere atfedilen rollerin farklı olması, gittikçe kadının bir birey olarak algilanmasına ve her iki cinsin de bir ülkenin kalkınmasında da ayrı ayrı değerlendirmesine sebep olmuştur. Ayrıca bu dönemde dikkat çeken bir diğer konu da kadın ve kalkınma arasındaki ciddi bir etkileşim olduğun fark edilmesidir. Bu sebepten Birleşmiş Milletler kadınların başta eğitimi olmak üzere statüsünü geliştirme yollarını aramaya başlamıştır (Kabeer, 2003, s. 13).

1975'lerde hem Birleşmiş Milletler'in girişimleri hem de feministlerin yarattığ1 bu düşünce değişiklikleriyle bağlantılı olarak kadınların kalkınma ile ilgili gündemi de değişmeye başlamıştır. Bu anlamda Birleşmiş Milletler, kadınların istenilen düzeyde kalkınmaya katılamamasının sağlanamamasını 'beşerî kaynak israfı' olarak nitelendirmiştir. Dolayısıyla kadınların, kalkınma sürecini çabuklaştıracağı anlayıșı hâkim olmaya başlamıștır. Bu anlayış 'kadmların kalkenmaya entegrasyonu' şeklinde tanımlamış̦tır (MClean, 2000, s. 180). Cinsiyet, ırk, dil, din ayrımı gözetmeden bir çaba sarf etmek Birleşmiş Milletler'in amaçları arasında olduğundan cinsiyet ayrımından kaynaklanan her türlü ayrımcilığı yok etmek bu teşkilatın görevleri arasında üst sıralara yükselmiştir. Aynı yıl Mexico City'de BM Kadının Statüsü Komisyonu tarafindan Birinci Dünya Kadın Konferansı düzenlenmiş, 1975-1985 yılları "Kadının İlerlemesi Onyılı" ilan edilmiştir. "Eşitlik, Kalkınma ve Barış" başlıklarıyla şekillenen bu konferansta amaç hem ulusal hem de uluslararası alanda kadınlarının cinsiyet ayrımcllğının önüne geçilmesi, üretime eşit düzeyde katılımın sağlanması ve yine bu bağlamda kalkınma imkânlarından da eşit düzeyde fayda sağlanmasıdır. Birinci Dünya Konferansı'nda oluşturulan "Dünya Eylem Planı”, kadınların bu dönemdeki kalkınma sürecine ilişkin gündemini de belirlemiştir. Buna bağlı olarak bu süreçten sonra pek çok hükümet; kadın sorunlarıyla ilgilenecek bürolar kurmuş, bu sorunlarla ilgilenecek daha çok eleman istihdam etmiştir. Dolayısıyla bu dönemde kadın sorunları belirli bir araştırma konusu haline gelmiş ve uygulamaya yönelik çalışmalara öncelik verilmiştir. Bunların neticesinde toplumsal cinsiyet perspektifinin, kadınlar açısından ülkelerde yaşanan değişim ve gelişmelerin irdelenmesine ve eylem politikaları üretilmesi için adımların atılmasına karar verilmiştir. Bu gelişmelerin tümü kadın hareketi ve sorunları açısından önemli bir dönüm noktası olmuştur (Ertürk, 1996, s. 347-348).

Bu yıllarda Kalkınmada Kadınlar Yaklaşımına yönelik yapılan eleștiriler, Kalkınma ve Kadınlar Yaklaşımın (WAD) şekillendirmiştir. Bu dönem kadınların ikincilleştirilmesinin özel mülkiyet ve kapitalizm yüzünden olduğunu iddia edenler, toplumsal cinsiyet eşitsizliklerinin ortadan kaldırlması için de öncelikle kapitalist sistemin sonlanması gerektiğini savunmuşlardır. Bu sebeple Kalkınma ve Kadınlar Yaklaşımı, üretim süreçlerini, üretim ve emek kavramlarını yeniden yorumlayarak, onları toplumsal cinsiyet perspektifiyle analiz etmişsir. Buna göre kadınların bedenlerinin ve emeklerinin hane içinde ve dışında erkekler tarafından sistematik olarak sömürüldüğü sistem ataerki olarak adlandırılmaktadır. Bu sömürü doğru orantılı bir şekilde sermaye sahipleri ve işçiler arasındaki düzeni besleğinden; kadınlar da hane içindeki bakım hizmetlerini, üretim faaliyetlerini karşıllksız olarak sevgi ilişkisi çerçevesinde gerçekleştirmekte bu yüzden bahsi edilen faaliyetler ekonomik olarak değerlendirilmemektedir (Yücel, 2016, s. 86-87). Nitekim bu yaklaşım kadınların; kalkınmanın bir parçası olduğunu savunmuş ve kalkınma süreçlerindeki ilişkiye odaklandığından kadınların sorunlarının ortaya konulmasında zaman zaman yetersiz kalmıştır.

Hem Kalkınmada Kadınlar Yaklaşımı (WAD) hem de Kadınlar ve Kalkınma Yaklaşımı (WID), müdahale stratejileri gelir getirici faaliyetlerde yoğunlaşarak kadınlara getireceği fazladan zaman yükünü dikkate almamışlardır. Ev işini, çocuk ve hasta bakımını aile içi alan olması nedeniyle üretim faaliyetleri plan ve projeleri içine almamışlardır (Yavuz ve Serdaroğlu, 2010, s. 65-66). Çünkü kadınların ailesi için harcadığı zamanın ve evde yaptı̆̆ çalışmaların toplumsal cinsiyet normlarını dönüştürücü bir etki yapması beklenemez (Erdut, 2011, s. 78). Bu açıdan bakıldığında her iki yaklaşım da toplumsal cinsiyeti tam anlamıyla destekler nitelikte değildir.

1980'lerde değişen dünya düzeniyle birlikte her alanda olduğu gibi cinsiyetler arasındaki eşitsizlikler de artmış ve bu süreçte feminist iktisadın da tesiriyle toplumsal cinsiyet alanındaki bakış açıları da gelişmiştir. 
$\mathrm{Bu}$ süreçte feministler arasında yaygınlaşmaya başlayan bir diğer yaklaşım da toplumsal cinsiyet ilişkilerinin çok boyutluluğuna dikkat çeken Toplumsal Cinsiyet ve Kalkınma Yaklaşımıdır (GAD). Bu yaklaşım, kadınların ve erkeklerin kültürel olarak pek çok eşitsizlik barındırdığını ileri sürmüştür. Dolayısıyla, bu yaklaşımda eşitsizlik yaratan güçlerin yani devletin ve kurumlarının politika üretmesi önerilmektedir (Yücel, 2016, s. 88-100). Ayrıca kadınların ev dışındaki üretimlere katllırken, erkeklerin de özel alandaki iş bölümüne katılmasının gerekli olduğunu savunmaktadır. Bu anlayış, sosyal kalkınmayı önemseyerek; sadece gelir getirici faaliyet yaratma amacıyla yetinmeyerek, sosyal eşitsizlikleri yok etmeye yönelik bilincin oluşmasını ve farkındalık yaratılmasını amaçlamaktadır. Bunu destekler nitelikte şu söylenebilir ki GAD sadece kadınlara odaklanmamıştır. Kalkınmanın kadınlar üzerindeki etkisini sorgulamış kadınların ve erkeklerin belirli rollerinin, sorumluluklarının, beklentilerini de dikkate alarak konunun arka planıyla da ilgilenmiştir (Rathgeber, 1989, s. 3).

Görülüyor ki kadınların ev içinde yaptıkları çalışmalar onlara ekonomik gelir sağlamadığı gibi patriarkal ideolojinin var olduğu toplumlarda da emekleri dikkate bile alınmadan yok sayılmaktadır. Bunun farkında olan neo-liberal piyasa da kadınları ucuz işgücüne yönlendirmekte, dolayısıyla kadınlar hem evde hem dışarıda yoğun bir çalışma temposuna maruz kalmakta üstelik emeklerinin tam karşılığını da alamamaktadırlar. Bu bağlamda GAD yaklaşımında kadınların güçlendirilmesi; açık bir şekilde tanımlanmasa bile dolaylı yoldan kadınların sorunlarının politik alanda gündeme getirmesi ve stratejik olarak belli başlıklar altında irdelenip çözümlenmesi şeklinde yorumlanabilir. Diğer bir ifadeyle bu yaklaşıma göre kadınların güçlendirilmesi, kadınların bilinç farkındalı̆ı̆na ve nesne olmaktan kurtulup özgürleşmelerine bağl1 kilınmıştır.

1985 yllında Nairobi'de düzenlenen konferansta önceki konferanslarda yapılan düzenleme ve alınan kararların değerlendirilmiş; kadınların statülerinin gelişimi için geleceğe yönelik stratejiler yapılmıştır. Yine de kadınlarla ilgili her konular rahatça ve özgürce tartı̧ılamamıştır. Ancak NGO formlarındaki çalışma gruplarında resmileşen Yeni Bir Çağ için Kadınlarla Kalkınma Alternatifleri Yaklaşımı (DAWN)ortaya çıkmışıır (Gökkaya, 2018, s. 230). Kadınların; başta cinsiyet temelli olmak üzere tüm eşitsizliklerden kurtulmasını, temel ihtiyaçların aslında temel haklar olarak kabul edilmesini, dünya halkının çoğunluğunun hayatta kalmasına öncelik verecek olan alternatif kalkınma süreçlerine duyulan ihtiyaçlarını dile getirmiştir. DAWN, kendisini yoksullaştırılmış Üçüncü Dünya kadınlarının temsilcisi olarak görmüş ve güçlendirmenin feminizmin kavramlaştırılması ve tenkitsel yansımalar açısından önemli ve elzem olduğunu belirtmiştir (Yavuz ve Serdaroğlu, 2010, s. 66-67). Ayrıca bu yıllarda İnsan Hakları İzleme Örgütü (HRW) bünyesinde de Kadınların İnsan Hakları Projesi hayata geçirilmiştir. Bu proje kadınların; toplumsal cinsiyet eşitsizliğinden kaynaklanan sorunlarının dizgesel olarak yetersiz temsil edildiğinin farkına varmalarında başlıca etken olmuştur. Bu bağlamda bu örgüt; Birleşmiş Milletler bünyesinde gerçekleşen girişimlerde kadınların haklarının savunulmasında, sorunlarını insan hakları çerçevesi içinde eşit şekilde temsil etmesinde önemli bir etken olmuştur (Çelik, 2011, s. 149-151).

1989'da kadınların birey olarak sahip olduğu hakların "her yerde her kadın için aynı" olduğu anlayışından hareket eden Birleşmiş Milletler Kadınlara Karş1 Her Türlü Ayrımcıllğın Önlenmesi Sözleşmesi (CEDAW), her türlü doğrudan ya da dolaylı ayrımcllı̆̆n yok edilmesi gerektiğini vurgulanmıştır. Buna ilaveten ayrımcıllğa neden olacak tüm kültürel kalıp ve davranışların dönüştürülmesi gerektiğinin de altını çizmiştir. (Acar, 2010, s. 197-198). Ayrıca CEDAW daha önce uluslararası sözleşmelerde olmayan iki hususu açık bir şekilde hüküm altına almıştır. Birincisi fiili eşitliğin sağlanması gereği, ikincisi kadınlara karşı ayrımcılığın ortadan kaldırılmasının önemidir. Bu iki unsurla birlikte ilk kez kadınlara yönelik cinsiyete dayalı ayrımcılığı önlemek için sadece yasal eşitliğin yeterli olmadığı, bu eşitliğin fiilen de olması gerektiği ve yaşamın her alanında sağlanmasının mukteza olduğu ileri sürülmüştür. Kadınlara karşı yapılan ayrımların ortadan kaldırılması amacıyla daha somut çözümlerin ve hatta daha etkili eylem planlarının yapılmasının şart olduğu bağlayıcı nitelikte bir uluslararası norm haline gelmiştir. $\mathrm{Bu}$ normlara dayanarak CEDAW’a göre kadınlara karşı ayrımcılık olduğu takdirde (Sancar, 2018, s. 43-44);

- Hak eşitliği ve insanlık onuruna saygı prensipleri ihlal edilir.

- Kadınların erkeklerle eşit şekilde yaşama katılmalarına engel teşkil eder.

- Toplumun ve ailenin refah düzeyinin artmasina mâni olunur.

- Kadınların yeteneklerinin gelişmeleri güçleşir.

Anlaşıldığ1 üzere CEDAW, kadınlara karşı ayrımcılığın önlenmesi için çıktığ1 bu yolda, sözleşme metninin içinde kadınların güçlendirilmesi şeklinde bir söyleme açıkça yer vermemiştir. Ancak bu ekonomik düzenin kurulmasında kadınlar ve erkekler arasındaki ayrımcılığın kaldırlmasındaki esas 
gayenin, kadınların her alanda özgürlüklerinin önünde engel olan cinsiyete dayalı her türlü ayrım, dışlama ve sınırın kaldırılması için güçlenmesi gerektiğini belli etmiştir. Buradan yola çıkarak hak ve eşitlik kavramlarıyla şekillenen CEDAW'a göre kadınların güçlenmelerinin; eğitim, sosyal, siyasal, ekonomik, sosyal ve kültürel alanlarda eşit olmaları gerektiği tanımına ulaşılabilir.

1990’lar kadınların güçlenmesi söyleminin açıkça kavram olarak ifade edildiği ve ön plana çıktığı bir dönemdir. Burada amaç, kadının gündelik yaşamını etkili bir biçimde idame ettirebilmesi için gerekli bilgi, beceri ve kaynaklara ulaşmasını sağlayarak kendi içsel kapasitesini geliştirmektir. İlk başlarda eşitlikçi ve güçlenme yaklaşımları birbirleriyle uyumlu gibi görülseler de esas olarak; eşitlikçi yaklaşımdan farklı olarak kadınların güçlenmesinde cinsiyet yapılanmasına dokunulmaksızın kadınların kendi ayakları üzerinde durmaları gereği vurgulamaktadır. Politik sonuçları açısından tehdit edici olmadığından; pek çok çevreden de kabul görmüştür. 1990’lı yıllara damgasını vuran güçlenme yaklaşımın kalkınmada kadın projelerinin merkezi haline gelmesi bu dönemde ortaya çıkan diğer gelişmelerle de çok yakından ilgidir (Ertürk, 1996, s. 349-350). Çünkü kalkınma anlayışını benimseyen toplumsal hareketler ve kadın hareketinin temsil ettiği bir eksen, güçlenmeyi; var olan düzene karşı hem bireysel hem de kolektif olarak yürütülen mücadelelerin arttırılması olarak görmektedir. Bu dönemdeki hâkim anlayış, kadınların ihtiyaçlarının içinde bulundukları toplumun sınıfsal, etnik, dini yapılarından da etkilendiği yönünde olmuştur (Toksöz, 2011, s. 206).

Bu süreçten sonra güçlendirme kavramı ulusal ve uluslararası alanlarda daha sık gündeme gelmeye başlamıştır. Literatürdeki mevcut kavramları kullandığı halde toplumsal cinsiyet eşitliği ve kalkınma arasında bağ kurarak onları güçlendirmeye çalşsan Dünya Bankası (WB) bundan sonraki tüm dokümanlarında kadınların güçlenmesinin tüm sosyal gelişim programlar için kilit bir kavram olması gerektiğini söylemiştir. Ayrıca güçlenmeyi; yoksulluğu azaltmanın temel bileşenlerinden biri ve kalkınma yardımlarının öncelikli hedefi olarak tanımlamıştır (World Bank, 1995, s. 145-151). Böylece güçlendirme kavramının alanı genişlemiş en küçük NGO’lardan Dünya Bankası'na kadar büyük bir alanı kapsayıcı olmuş, plan ve projelerin temel bileşeni haline gelmiştir (Toksöz, 2011, s. 203). Fakat güçlendirme farklı oyunculara farklı anlamlar ifade etmeye başlamışır (Yavuz ve Serdaroğlu, 2010, s. 150).

Öncelikle güçlendirme konusunda kersal bölgelerdeki kadınlar dikkate alınmış ve gelişimin kilit unsurları olarak görülmeye başlanmıştır. Bu bağlamda kırsal bölgedeki kadınların güçlenmesi, yeni modeller ve süreçler oluşturmada bütünsel yaklaşımın odak noktası olarak görülmüştür. Fiziksel refahları, sağlık, güvenlik ve bedensel bütünlükleri dahi genellikle kendi kontrollerinin ötesinde olduğu dile getirilmiştir Dolayısıyla kadınların kırsal olarak güçlenmesi, toplumsal güçlendirme, örgütsel güçlendirme, politik güçlendirme ve psikolojik güçlendirme olarak dört ana grupta toplanmıştır(Allahdadi, 2011, s.214):

- Toplumsal güçlendirme: Kırsal alanda yaşayan kadınların yeni ve faydalı bilgilere erişimi, yeni becerilere ve yeteneklere sahip olması için yardımcı olunması bu yolla kendine güvenin sağlanmasıdır.

- Örgütsel güçlendirme: Kırsal alanda turizmin ve tarım kooperatiflerinin gelişimi yoluyla teknolojinin kalkınma için ne kadar faydalı olduğu hususunda farkındalık yaratmaktır.

- Politik güçlendirme: Kırsal kesimde yaşayan kadınları ve kırsal toplulukları etkileyen sorunları tartışmak için hükümetle, sektördeki insanlarla ve diğer kadınlarla etkin bir ağ oluşturmaktır.

- Psikolojik güçlendirme:_Özgüvenin artması ve yeni gruplara katılımın sağlanmasıdır.

$\mathrm{Bu}$ dönemde uygulanan politikalarda kırsal kesimdeki kadınların güçlenmesiyle birlikte erkeklerle kadınlar arasında bir güç dengesi oluşturulacağına inanılmış, bu durumun sadece kadınlara değil; bir bütün olarak siyasi, ekonomik ve kültürel açıdan toplumun her kesimine fayda sağlayacağı düşüncesi hâkim olmuştur. Birleşmiş Milletler ve diğer kalkınma ajanslarının hemen hemen hepsi politikalarında; kadın konularını ilgilendiren maddeleri gündemlerine daha sık almaya, hatta bu konulara özel başlıklar açmaya başlamışardır (Connelly veBarriteau, 2000, s. 102).

1995'lerde Birleşmiş Milletler Pekin'de şimdiye kadar yapilanların en büyüğü olan IV. Uluslararası Dünya Konferans'ı düzenlemiştir. 189 ülkeyi temsilen binlerce delege ve katıllımcının olduğu bu konferansta, kadın sorunlarının evrensel olduğu mesajı verilmiştir. Hükümetler burada ilk kez ulusal politikalarında yapacakları değişikliklerden, atacakları adımlardan bahsetmişler ve hatta kendilerini bağlayıcı taahhütlerde bulunup ulusal planlar hazırlamışlardır. Böylelikle Pekin Eylem Platformu, dünyada değişen güçlenme anlayışının somut bir ifadesi olmuştur. Kadınların güçlenmesi kavramını ana felsefesi yapan platformda dile getirilen konulardan en önemlisi, kadınlar için yapılan çalışmaların ilave çalışmalar şeklinde değil ana politikaların ayrılmaz bir parçası olduğunun kabul edilmesinin gerektiği olmuştur. Ayrıca kadın 
sorunları ancak merkeze konularak hareket edildiğinde çözüme kavuşacağının da altı çizilmiştir (Uluslararası Kadın Sağlık Örgütü, 2001, s. 21-22). Bunlara ilaveten bu dönemden sonra her yil Birleşmiş Milletler Kalkınma Programı (UNDP) tarafından; insani gelişme raporları yayımlanmaya başlamıştır. İnsani gelişme kavramını kişi başı gelir hesaplarının ötesinde taşıyan bu raporda; insanların özgürlükleri, kişilikleri, gelişimleri de dikkate alınması gerektiği vurgulanmış, insanların hayat kalitelerinin artması olarak tanımlamışıı (Demir, 2006, s. 2). Aynı yıl Toplumsal Cinsiyet ve İnsani Gelişme başlı̆̆ı altında yayımlanan raporda; dünyada yaşayan 1,3 milyar yoksul insanın \%70'inin kadın olduğuna dikkat çekilmiştir (Özyol, 2013, s. 132).

Dünyada bu hareketlenmeler sürerken kadın hakları ve toplumsal cinsiyet eşitliği konusu, elbette Avrupa Birliği’’nin de gündeminde yer almıştır. 1950’lerden beri cinsiyet eşitliğinin sağlanması konusunda çeşitli çalışmalar yapan Birlik, 1997 yllında imzalanan Amsterdam Antlaşması ile de resmi olarak; kadınerkek eşitliğini Topluluğun bir görevi olduğunu bildirmiştir. Aynı yıl içinde üye devletler için İstihdam Politikası Kuralları benimsemiştir. Dört dayanaktan oluşan İstihdam Kuralları'nın dördüncü dayanağ1 'Fırsat Eşitliğidir' ki buna göre amaç; kadın ve erkeklerin işgücü piyasasında eşit firsatlara sahip olacakları, özel ve kamu hayatlarını daha iyi dengeleyebilecekleri şartları yaratmak ve kadınların işgücü piyasalarına katılım oranlarını artırmaktır. Görüldüğü gibi Avrupa Birliğı’ndeki çalışmalarda bu yıllarda kadınların güçlendirilmesi kavramından doğrudan bahsedilmese bile ekonomik anlamda gelişmelerinin sağlanması gerekliliğinden ve temel hak ve özgürlüklerinden sıkılıkla bahsedilmiştir. Üye devletlerden kadınların ekonomik olarak kalkınmasının şartı aranmış; kadın-erkek eşitliği konusu Birlik'e giriş şartlarından en önemlisi olmuştur. Bunun sonucunda kadınların istihdamlarının artırlmasıyla beraber özel ve iş yaşamlarının da uyumu ile ilgili konular öne çıkmıştır. Örneğin; çocuk bakımının desteklenmesi, kadın işsizliğinin azaltılması ve istihdamda kadın dostu politikaların benimsenmesi eşitlik politikalarının ana gündemi haline gelmiştir. Bunun için Avrupa Konseyi 2000 yılında Lizbon Zirvesi’nde toplanmış, kadın istihdamının on yil sonra \%60'a yükselmesini öngörmüş ve bu doğrultuda kararlar almışır. Bu kararlarda kadınların istihdama katılması oldukça önemli görülmüş fakat çalışma hakkı gibi ekonomik bir haktan söz edilmemiştir. Buradan anlaşılmaktadır ki sosyo-ekonomik eşitliğe ve toplumsal-kültürel yapılarda değişikliklere gidilmesi istenmekte ancak bu durum ekonomik yapı ve politikalar için konuşulmamaktadır. Diğer bir ifadeyle kadının güçlenmesi arzu edilmekte lakin bu durumun önemli bir nedeninin eşit olmayan gelir dağllımından kaynaklı olduğu görülmemektedir(Koray, 2011, s. 22).

2000 yllinda Birleşmiş Milletler (BM) Pekin+5 özel oturumuyla 15 ylllık hedefler belirleyerek; bunu Binyıl Kalkınma Hedefleri olarak adlandırmıştır. Ulusal ve uluslararası kurum ve kuruluşların odak noktası haline gelen, kadınların güçlendirilmesi için önemli adımlardan birini atan ve bu olguyu dünya çapında sürdürülebilir kalkınmanın sağlanmasının önemli bir hedefi haline getiren organizasyonun belirlediği toplamda sekiz hedeften biri kadın-erkek eşitliğinin sağlanması diğeri de kadınların konumunun güçlendirilmesidir. Sonuç belgesinin başlangıç bölümünde de Eylem Platformu'nun hedefini, kadınların güçlendirilmesi olarak koymuş ve genel hatlarıyla çerçeveyi belirlemiştir. BM Kalkınma Programı (UNDP), Pekin+5 ile kadınların eğitim, ekonomi, siyasi alanda güçlendirilmesi konusunda söz sahibi olmaları demokrasinin temel koşullarından biri kabul edilmiş ve ülkelerin çoğu da anlaşmalara imza atarak bu gerçeği kabul etmiştir. Bu dönemde Dünya Bankası, tüm göstergelerin belirli bir disiplin çerçevesinde takibi, doğru veri elde edilmesi ve çıkan sonuçların değerlendirilmesi için UNDP'nin önderliğinde UNESCO, ILO, FAO, UNICEF, WHO gibi önemli uluslararası kuruluşların da görev aldığı Dünya Kalkınma Raporu'nu hazırlamış ve bu raporda güçlendirmenin, kavram olarak öneminden açı bir şekilde bahsetmiştir. Buna göre Dünya Bankası, güçlenmeyi daha çok yoksulluk ve yoksullukla mücadele çerçevesinde ele almış, eylem ve seçim özgürlüğün genişletilmesi süreci olarak tanımlamıştır. Ayrıca güçlenmeyi, bireyin kendi yaşamını etkileyecek olan karar ve kaynaklar üzerinde gücünü ve otoritesini artırması şeklinde tanımlamıştır (World Bank, 2000, s. 117-118). Yani güçlenme; neoliberal politika çizgisinde, yoksul insanları piyasaya yönlendirmeyi sağlayan bir araç olarak değerlendirilmiştir. Buradan hareketle Dünya Bankası güçlenmeyi; yoksul insanların varlık ve yapabilirliklerini genişletebilmeleri, kendi hayatlarını etkileyen kurumlar üzerindeki etkileri, kontrolleri ve aktif katılımlarını sağlamak olarak da görmüştür (Karaçay vd., 2014, s. 15-31). Ayrıca, 2000/01 Dünya Kalkınma Raporu'nun Güçlenme bölümünde toplumsal cinsiyet ile ilişkili ayrımcı uygulamaların din, ırk ve sosyal statü ile birlikte bireyleri nasıl piyasadan uzaklaştırıp fakirlik tuzağına düşürdüğünden; bu ayrımc1 uygulamaların ve cinsiyet eşitsizliğinin önlenmesi de ancak kadının güçlendirilmesi yoluyla gerçekleşebileceğinden de bahsetmiştir. Nitekim işgücü piyasalarında kadınların erkeklere göre dezavantajlı konumlarının devam ettiği vurgulanmış, dünyadaki iyileşmelere rağmen toplumsal cinsiyet eşitliği hususunda henüz istenilen seviyeye ulaşılamadığı, önemli sorunların hâlâ devam ettiği, bu yüzden daha atılması gereken çok önemli adımların 
olduğuna da dikkat çekilmiştir. 2000/01 Dünya Kalkınma Raporu detaylı şekilde incelendiğinde, ulusal ve uluslararası politikaların 'sürdürülebilirliğine' de dikkat çektiği görülmektedir. Sürdürülebilirlik sözcüğünün bu dönemde ideolojik olarak ulusal ve uluslararası politikalara girmesinin tesadüf olduğu söylenemez. Türkçe'ye sürdürülebilirlik olarak geçen "sustainability" sözcüğü devamllık arz etme durumuna atıf yaptığından sürekli olmak ifadesi ile karıştırlmaması gerekmektedir. Şöyle ki bir olgunun sürekli olması herhangi bir iradeden bağımsız olarak gerçekleşebilirken, sürdürülebilir olması bir iradenin bu doğrultuda tercihine bağlıdır. İşte bu açıdan sürdürülebilirlik sözcügü kalkınma kavramı ile birlikte kullanıldığında; toplumun ekonomik ve sosyal gelişiminin sürekli olması için gereken iradenin doğru ve yeterli biçimde hayata geçirilip, geçirilmediği ile ilgilidir (Akgül, 2010, s. 134).

Tüm bunlara bağlı olarak bu dönemden sonra kalkınma hedeflerinde sıklıkla görülen sürdürülebilirlik kavramı, kadınların güçlendirilmesi konusunda da sürece dâhil olmuştur. Yani toplumsal cinsiyet eşitliği alalındaki yapılan çalışmalardan ziyade bunların kesintisiz devamlılı̆ı önem arz etmiştir. Ayrıca bu süreçte sıklıkla Birleşmiş Milletler ve Dünya Bankası bu dönemden sonra yapacakları çalışmaların hemen hepsinde kadınların güçlendirilmesi için, ulusal ve uluslararası düzeyde birtakım yaptırımların olması gerektiğini savunmuşlardır. Buna ek olarak kadınlar lehine olması gereken tüm bu iradelerin doğru kullanıldığı takdirde kadınların güçleneceği söylenmiştir. Dolayısıyla 2000'li yıllardan sonra Birleşmiş Milletler ve Dünya Bankası için kadınların güçlendirilmesi, temel haklarda olmak üzere; sosyal, ekonomik, siyasal alanlardaki tüm gelişmelerin uyumlu bir istikrar içinde olması gerektiği manasında yorumlanabilir.

Ayrıca Uluslararası Çalışma Örgütü (ILO) tarafindan ilk kez geliştirilen ve uygulanan bir sistem de Toplumsal Cinsiyet Denetimi'dir. Birleşmiş Milletler sisteminde buna benzer geliştirilen araçların ilk örneği olup; daha sonra birçok ülkede başarılı bir şekilde uygulanarak, kurumların toplumsal cinsiyet yaklaşımını ana akım haline getirmelerinde katkı sağlamıştır. Ekip için denetim tabiri kullanılsa da aslında bir öğrenme süreci olduğu söylenebilir. Amacı, toplumsal cinsiyetin kurumsal alan ve hizmetlerde ne şekilde ve nasıl ana akım haline getirileceğinin çalışmalarını yapmaktır.

2007'de Dünya Bankası Cinsiyet Faaliyetleri Planını ortaya koymuştur. Bu plana göre işgücü; tarım, finans ve altyapı sektörlerinde cinsiyet temeline odaklandırılmıştır. Ek olarak planın temel kaynaklarından biri kadınların güçlendirilmesinin, ekonomik istikrar üzerinde etkili olduğudur. Cinsiyet Faaliyet Raporu'nda kadın erkek arasındaki eşitsizliğin ancak;

- Kadınların eğitim seviyesinin artırılması,

- Okur-yazarlık oranlarının artırilmas1,

- Kredilere ulaşmalarının kolaylaştırılması,

- Sağlık programlarının geliştirilmesi,

- Aile destek politikalarının güçlendirilmesi yollarıyla azaltılacağını ve ortadan kalkacağı ifade edilmektedir (Güzel, 2001, s. 83-84).

2007 yllında ABD'de başlayan ve çok geçmeden dünyada etkisini gösteren ekonomik krizin yol açtığ1 daralma sonucunda genel olarak ülkelerdeki büyüme oranları düşmüş, işsizlik oranları artmıştır. Bu dönemde kadınlar da hanenin azalan gelirine katkı sağlamak amacıyla işgücüne dâhil olmuşlardır. Dolayısıyla kadınların işgücüne katılım payı artsa da patriarkal kültürlerin daha güçlü olduğu toplumlarda bu payın çoğu enformel sektöre kaymış veya onları ücretsiz aile işçisi olmaya yöneltmiştir. İlerleyen dönemde krizin etkin olarak hissedildiği 2008 yllinda ILO tarafindan 'Adil Bir Küreselleşme İçin Sosyal Adalet Bildirgesi' kabul edilmiş ve tüm üyelere dört ana stratejiye dayanan hedeflerini gerçekleştirmek için çalışmaları bildirilmiştir. Bildirgede, ILO'nun insan onuruna yakışır istihdam oluşturmaya yönelik çalışmalar yapmak istediğine atıfta bulunularak; kadın-erkek eşitliği ve ayrımcılık yapılmaması konusunda vurgular yapılmıştır. 2009 yllına gelindiğinde ILO, "Krizden Çıkış: Küresel İşler Paktı" belgesini oybirliğiyle benimsemiştir. Burada mevcut krizin, yeni cinsiyet politikaları geliştirilmesi hususunda bir firsat olabileceği, tedbir paketlerinde kadınlarla erkeklerin eşit düzeyde değerlendirilmeye alınmasının gerekliliği üzerinde durulmuştur (Kadın Komitesi Hak-İş, 2017, s. 39).

2010 ylına gelindiğinde Birleşmiş Milletler Kadın Birimini oluşturarak, toplumsal cinsiyet eşitliği alanındaki çalsşmaları daha aktif şekilde yürütmek istemiştir. Bu birim de reform çalışmalanı kapsamında kendi bünyesinde Birleşmiş Milletler Kadınların Güçlenmesi ve Toplumsal Cinsiyet Eşitliği Birimi’ni kurmuş, Birleşmiş Milletlerin toplumsal cinsiyet eşitliği ve kadınların güçlendirilmesi alanında faaliyet gösteren dört organını birleştirmiştir. Bunlar; 
- Kadınların İlerlemesi Birimi (DAW),

- Kadınların İlerlemesi için Araştırma ve Eğitim Enstitüsü (INSTRAW),

- Cinsiyet Sorunları ve Kadınların Gelişimi Konusunda Özel Danışman Ofisi (OSAGI),

- Birleşmiş Milletler Kadınlar için Kalkınma Fonu (UNIFEM)'dir.

Aynı yıl önemli bir gelişme daha olmuş; Kadınların Güçlenmesi Birimi (UNWOMEN) ve Toplumsal Cinsiyet Eşitliği Birimi tarafindan geliştirilen Kadınların Güçlenmesi Prensipleri 7 madde ile yürürlüğe girmiştir (Kadın Komitesi Hak-İş, 2017, s. 20-21). Bu prensipler; toplum her alanında toplumsal cinsiyet eşitliğinin sağlanması amacıyla şirketlere öneriler sunmuştur. Bu öneriler şunlardır (UNWOMEN, 2010):

- İş yaşamında cinsiyet eşitliği için üst düzeyde liderlik ortaya koyulmast,

- Kadın ve erkek tüm çalışanlara işyerinde adil davranılması, insan hakları ve ayrımcllık yasağ1 ilkelerine sayg1 gösterilmesi ve destek verilmesi,

- Cinsiyet ayırmaksızın tüm bireylerin sağlık, güvenlik ve refahlarının sağlanması,

- Kadınların eğitim, öğretim ve meslek gelişim konusunda teşvik edilmesi,

- İşyerlerinde girişim, iş geliştirme, tedarik zinciri ve pazarlama süreçlerine ilişkin uygulamaların kadınların güçlenmesine yarayacak şekilde yürütülmesini sağlaması,

- Toplumsal inisiyatifler ve destekler aracıllğıyla eşitliğin teşvik edilmesi,

- Cinsiyet eşitliğine ilişkin ilerlemenin ölçülmesi ve sonuçlarının kamuoyu ile paylaşılmasıdır.

Birleşmiş Milletler Kadınların Güçlenmesi Prensipleri’ne göre güçlendirme için sürecin doğru tahlili sonucun değişmesi için önemlidir. Buna ilaveten UNDP, kadınların güçlendirilmesi çerçevesinde kadınların kalkınmasının, her biri için güçlenmenin temel bileşen olduğu ve bunların 5 temel alanda görülmesi gerektiğini belirtmiştir. Bu alanlar: refah, erişim, farkındalık, katılım ve kontroldür. Kadınların kalkınması için ise eşitliğin, bu 5 ana basamakta da görülmesi gerektiği açıcça ifade edilmiştir (Örümcü, 2015, s. 44).

2012'de Dünya Bankası diğer kalkınma raporlarına ek olarak "Cinsiyet Eşitliği ve Kalkınma Konusunda Dünya Kalkınma Raporu” adıyla bir Kalkınma Raporu daha yayımlamıştır. Bu raporda, toplumsal cinsiyet eşitliği ile ilgili problemlerin hem kalkınma hem de politika açısından önem taşıdığına dikkat çekilmiş, bu sorunları düzeltmek için de yapılacak tüm çalışmaların öncelikli olduğunun altı çizilmiştir. Bu raporda ileriye yönelik politikalar açısından dikkati çeken konunun toplumsal cinsiyet olduğu görülmekte olup dört kritik alan üzerinde durulmuştur. Bu maddeler şunlardır (Kadın Komitesi Hak-İş, 2017, s. 42):

- Kadın ölümlerinin ve eğitim farklılıklarının azaltılması,

- Ekonomik firsatlara erişim ve onları kullanmadaki eşitsizliklerinin kapatılması,

- Toplumda sesini duyurma açısından ayrıcalıkların yok edilmesi,

- Toplumsal cinsiyet eşitsizliklerinin kuşaklar boyunca devam etmesinin sınırlanmasıdır.

Dünya Bankasının en önemli açılımlardan biri de yine 2015 yılında ortaya koyduğu, 2016-2023 yılları arasını kapsayan kalkınma stratejisidir. Bu strateji; kadınların güçlendirilmesi ve toplumsal cinsiyet eşitliğinin sağlanması hususunda ülke bazında birçok projeye destek vermektedir. Dünya Bankası'nın yürüttügü çalışmalarda yıllar geçtikçe kadınların güçlenmesi adına daha çok çalışmanın ve toplumsal cinsiyet eşitsizliklerinin farkındalığının artması için daha çok gayretin olduğunu görülmektedir. Bütün kalkınma raporlarının hepsine baktığımızda kavram olarak değinilmediği zamanlarda dahi kadınların güçlendirilmesinin, kişisel anlamda gelişmesiyle ve bunların önündeki engellerin kalkmasıyla mümkün olacağına dikkat çekilmiştir.

Aynı yıl Milenyum Kalkınma Hedefleri'nin değerlendirilmesi sonrası, Birleşmiş Milletler tarafından da 2030 Sürdürülebilir Kalkınma Gündemi de oluşturulmuş ve burada 17 hedef belirlenmiştir. Bu hedefler içinde toplumsal cinsiyet eşitliğinin sağlanması ve kadınların güçlendirilmesi konuları önemini korumuştur.

Gündemde ele alınan konular şunlardır:

- Kadınlara ve kız çocuklarına yönelik her türlü ayrımcılığa son verilmesi,

- Kamu alanları ve özel alanlarda, tüm kadınlara ve kız çocuklarına yönelik her türlü şiddetin yok edilmesi, 
- Çocuk evliliği ve zorla evlendirilme ile kadın sünneti gibi uygulamaların sonlandırılması,

- Ulusal şartlara uygun şekilde kamu hizmetlerinin, altyapının ve sosyal koruma politikalarının sağlanması ile hane halkı ve aile içerisinde sorumlulukların paylaşımının teşvik edilmesi yollarıyla ücretsiz bakım ve ev işlerinin tanınması ve bunlara değer atfedilmesi,

- Kadınların karar alma süreçlerinin her seviyesinde tam ve etkili katılımıyla liderlik etmeleri için eşit firsatlar sağlanması.

Uluslararası Nüfus ve Kalkınma Konferansı Eylem Programı, Pekin Eylem Platformu ve bunların gözden geçirme konferanslarının sonuç dokümanları çerçevesinde mutabık kalınan şekilde cinsel ve üreme sağlığına ve üreme haklarına evrensel erişim sağlanmasıdır. Bu madde de 3 başlığa ayrılmış olup şunlardır:

- Kadınların ulusal yasalarla uyumlu olacak şekilde ekonomik kaynakların tümüne sahip olma konusunda eşit haklara sahip olmaları için reformlar yapılması,

- Kadınların güçlendirilmesini destekleyen özellikle bilgi ve iletişim teknolojilerinin kullanımının artırilmas1,

- Toplumsal cinsiyet eşitliğinin desteklenmesi ile kadınların ve kız çocuklarının her seviyede güçlendirilmesi için sağlam politikalarla uygulanabilir mevzuatların kabul edilmesidir.

2015 yılında düzenlenen, 2030 Sürdürülebilir Kalkınma Gündemi uluslararası kuruluşlar için önemli bir referans olmuştur (Kadın Komitesi Hak-Isss, 2017, s. 31). Gündem başlıklarına bakıldığında görülmektedir ki; kadınların güçlendirilmesi Birleşmiş Milletler için gittikçe daha büyük önem arz etmeye başlamıştır. Ayrıca aynı yıl İstanbul'da 20 ülkeden 36 temsilci, Birleşmiş Milletler Kadın Örgütü ve Uluslararası Çalışma Örgütü’nün katılımıyla Kadın-20 (W20) Zirvesi düzenlenmiştir. Bu zirvede ulusal boyutta, büyümeden, refah artışından toplumdaki her kesimin faydalanması amaçlanmıştır. Bu kapsamda kadın istihdamına da gündem içinde yer almışır (Yıldız, 2005, s. 87). W20'nin hedefleri arasında kadınların ekonomik konumlarının iyileştirilmesi, işgücüne katılım oranlarının artırılması ve toplumsal cinsiyet eşitsizliğine bağlı ücret farklarının ortadan kaldırılması vardır. Ülkelerin ilerlemelerini ölçebilmek için onlara karne sistemini getiren W20 içinde yer alan 11 maddelik tavsiyeler incelendiğinde; kadınları ekonomik alanda güçlendirme birinci maddede yer almaktadır. Kadınların güçlendirilmesinin öncelikle eğitim, istihdam ve girişimcilik arasındaki bağlantıların güçlü olmasıyla yakından ilgili olduğu savunulmuştur. Ayrıca yönetici konumdaki kadınların sayılarının artırılması, işyerlerinde ayrımcılığın kaldırılması, firsat eşitliğinin sağlanması, kadınların ekonomik, politik, sosyal ağlarının kuvvetlendirilmesi, çalışma şartlarının iyileştirilmesi bu maddeler içindedir.

2016 yılında İslam İşbirliği Teşkilatı'nın kadın odaklı faaliyetlerinde ilerleme olduğu, üyesi olduğu ülkelerdeki kadınların güçlendirilmesini öncelikli konuları arasına aldığı görülmektedir. Bu çerçevede 13. İslam Zirvesi'nin başlığını "Adalet ve Barış için Birlik ve Dayanışma Toplantısı" olarak belirlemiştir. Bu toplantıda 2025'e kadar hayata geçirilmesi arzu edilen hedefler belirlemiştir. Eylem planının öncelikli konuları: kadınların güçlendirilmesi, aile refahı ve sosyal güvenlik olmuştur. Kadınlara karşı ayrımcılığın, tacizin, yoksulluğun ve şiddetin onları güçüzleştirdiğini, ayrıca duygusal sağlıkları üzerinde negatif etki yarattı̆g tespitinde bulunulmuştur. Mevcut olan eşitsizliklerin uygun politikalarla düşürülmesi hedeflenmiştir. Kadınların güçlendirilmesinin, ailenin korunması, anne çocuk sağlığı, gençliğin kapasitesinin inşası, yaşı bakımlarında sivil toplumun katılımının toplumun gelişimi için gerekli olduğu gibi tavsiyelerde bulunulmuştur. Görüldüğü üzere İslam İşbirliği Teşkilatı kadınları bir birey olarak değil, ailenin bir parçası olduğu için güçlendirilmelerini desteklemiş, anneliğinin ve aile kurumunun idamesindeki etkinliğinden dolayı gerekli görmüştür. Kadının fitratı gibi kavramlara atıfta bulunan örgütün, kadınlardan bahsetmesine rağmen; toplumsal cinsiyet eşitliği hususunda bir duruş sergilediği söylenememektedir.

\section{Tartışma, Değerlendirme ve Sonuç}

Kalkınma; tarihsel açıdan incelendiğinde kavramsal olarak farklı anlamlar, terminolojik olarak çeşitlilikler göstermektir. Güç kavramı da kalkınmaya benzer şekilde kendi içinde dinamik bir yapısı olup, karmaşı bir metodolojiye sahiptir. Dolayısıyla bu iki kavramın bir arada kullanılması zaten tartşsmalara ve hatta anlaşmazlıklara yol açabilecekken, 'kalkınmada kadınların güçlendirilmesi' hususunda sistematik bir neticeye ulaşmak mümkün olmayabilir. Ancak özellikle son yıllarda uluslararası kalkınma politikalarında toplumsal cinsiyet eşitliğinin sağlanması için kadınların güçlendirilmesine yönelik müdahaleler artmış, dikkate alınması gereken bir konu olarak karşımıza çıkmıştır. 
Uluslararası kalkınma politikalarında; genellikle istihdam firsatlarını ve üretim gelirlerini artırmak, sosyal hizmetlerin alanını genişletmek gibi amaçlara ulaşmak için kalkınmaya yönelik programlara yer verilmiştir. Bütün bu hizmetleri kapsayıcı şekilde makro düzeyde büyüme hedefleriyle ilgili cinsiyete dayalı uygulamalara öncelik tanınsa da ne yazık ki tam olarak yerini bulamamıştır. Kalkınma alanı içinde cinsiyete dayalı rollerde boşluklar teorik olarak kapatılmaya çalışılmış olup bu uygulamaların çoğu neo-liberal politikaların da etkisiyle; temelinde cinsiyet hiyerarşisini daha da pekiştirmeye neden olmuştur. Çünkü uluslararası kalkınma politikaları uygulamaları kadınları; iktisadi bir aktör olarak değil amaca giden önemli bir araç olarak görmüştür. Ayrıca bu süreçte kadınlar; yaşadıkları toplumun kendilerine dayattığı hane içindeki 'asıl' görevlerini eksiksiz yerine getirmeye çalıştıklarından, çoğunlukla çalışma saatleri esnek, sigortasız, güvencesiz işlerde çalşşmaya yönelmiş ve/veya yöneltilmişlerdir. Başka bir ifadeyle kadınların üretim sürecine daha fazla dâhil edilip, piyasa içinde daha üretken ve verimli olması için yapılan uygulamalar, toplumların bilinç düzeylerinde ve toplumsal cinsiyet yapılanmalarında bir değişiklik olmadan programa alındığından birtakım çelişkilere ve sıkıntılara sebep olmuştur.

Son yıllarda kalkınma sürecinde uygulanan uluslararası politikaların, hedefe ulaşmak için kadınların güçlendirilmesi de önemli bir taahhüt olarak karşımıza çıkmaktadır. Bu nedenle ulusal ve uluslararası aktörler kadınların güçlendirilmesi hususunda değerlendirme yapmak üzere belirli göstergelere ihtiyaç duymuşlardır. Nitekim bu güçlendirilmenin değerlendirilmesi, kaynakları ve varlıkları elinde tutan siyasi ve/veya finansal karar vericiler tarafindan yapildığından hem bireysel hem de ulusal düzeyde tutarlı bir karşılaştırılabilirlik yapılması açısından sorun teşkil etmektedir. Çünkü güçlendirilme güç kavramı ile yakından ilişkili olup, gücün var olması bir tarafın daha az güçlü olgusunun kabulü ile mümkündür. Dolayısıyla kadınların güçlendirilmesi, güçlü olan tarafin kontrolü ile sağlanacağından temelinde kaynaklar üzerindeki finansal, toplumsal ve siyasal hâkimiyetin yönü ile ifade edilmektedir. Bu yüzden uygulanan uluslararası politikalarda kadınların güçlendirilmesi, gücü temsil eden aktörün veya aktörlerin yönetiminde olduğundan ölçüm gündemini ileriye taşımak için sürekli analiz ve araştırmanın olması gereklidir. 1990’lardan sonra kadınların güçlendirilmesi; kadın haklarından yana güç ilişkilerini dönüştürmek ve kadınerkek eşitliği hususunda daha fazla gayret etmek, toplumsal cinsiyet eşitliği sisteminde yer alan standartları sağlamakla ilgili bir yaklaşım olmuştur. Bu dönem özellikle insan hakları konusundaki iddialar, kadınların güçlendirmesinin evrensel bir bakış açısıyla irdelenmesinin gerekli olduğunu belirtmede önemli bir rol oynamıştır. Gerçekte de kadınlar için güçlenme yolu başkası eliyle değil, içsel benlik hâkimiyeti, bilinç yükseltme, bireysel değişim, eşitsizliklerin farkına varma ve harekete geçme yoluyla açılabilir.

Son olarak uluslararası kalkınma politikalarında yapılan çalışmaların, kadınların güçlendirilmesi ve toplumsal cinsiyet eşitliği bağlamında tümüyle olumsuz gelişmeler olarak da algılanmaması gerekmektedir. Diğer bir ifadeyle kadınlar uluslararası kalkınma politikalarında şarta bağlı bir sonuç olsa da, ekonomik kaynaklara eriştikleri zaman hayatlarının diğer alanlarında da pozitif yönlü değişiklik yapabildikleri bir gerçektir. Hedeflenen politikalarda toplumsal cinsiyet eşitliği alg1s1 ve kayg1sı düşük olduğu sürece, kadınlara yönelik dönüştürücü etkisi de tartışılmaya devam edecektir.

\section{Etik Beyan}

"Uluslararası Kalkınma Politikaları ve Kadınlarm Güclendirilmesi Üz̧erine Bir Değerlendirme” başlıklı çalışmanın yazım sürecinde bilimsel, etik ve alıntı kurallarına uyulmuş; toplanan veriler üzerinde herhangi bir tahrifat yapılmamış ve bu çalışma herhangi başka bir akademik yayın ortamına değerlendirme için gönderilmemiştir. $\mathrm{Bu}$ araştırmada doküman incelemesi yapıldığından etik kurul kararı zorunluluğu bulunmamaktadır.

\section{Kaynakça}

Acar, F. (2010). Türkiye'de toplumsal cinsiyet tartışmaları: eșitsizlikler mücadeleler kazanımlar. İçinde H. Durudoğan, F. Göksen, B. E. Oder ve D. Yükseker (edt.), Kadinlarn insan haklarnnda ulusaliustï standartlar ve denetim: Cedaw örneği bağlaminda baž gö̋lemler (ss. 197-206). İstanbul: Koç Üniversitesi Yayınları.

Allahdadi, F. (2011). Towards rural women's empowerment and poverty reduction in Iran. Life Science Journal, 8(2), 213-216. Erişim adresi: http://www.lifesciencesite.com/lsj/life0802/26_4742life0802_213_216.pdf

Akgül, U. (2010). Sürdürülebilir kalkınma: Uygulamalı antropolojinin eylem alanı. A.Ü. Dil ve Tarib Coğrafya Fakültesi Dergisi, 1(24).

Balkız, Ö. I., ve Öztürk, E. (2013). Neo-liberal gelişme anlayışı ve kadın: Mikro finans uygulamaları kadınları güçlendiriyor mu? Mediterranean Journal of Humanities, 3(2), 1-21. doi: 10.13114/mjh/201322451

Connelly, J. L. \& Barriteau, P. (2000). Theoretical Perspectives on Gender and Development Feminism and Development: In . M. P., T. M. Li, M. Mcdonald, J. L. (Eds), Theoretical perspectives (pp. 51-59). Ottova: IDRC Books. 
Çelik, Ö. (2011). Kadınların insan hakları hareketi. Gą̧i Üniversitesi İktisadi ve İdari Bilimler Fakültesi Dergisi, 14(1)1, 149-170. Erişim adresi:http://static.dergipark.org.tr/article-download/4495/88c3/c0f2/imp-JA39CE49JT$0 . p d f ?$

Demir, S. (2006). Birleşmiş Milletler kalkınma programı insani gelişme endeksi ve Türkiye açısından değerlendirme, Ankara: Sosyal Sektörler ve Koordinasyon Genel Müdürlüğü. Erişim adresi: http://file.setav.org/Files/Pdf/bm-kalkinmaprogrami---turkiye-degerlendirmesi.pdf

Dulupçu, M. A. (1999). Kalkınma iktisadı üzerine bazı düşünceler: İdeolojik-pratik-teorik bir sorgulama. Yönetim ve Ekonomi-Celal Bayar Üniversitesi IIBF Dergisi, 5, 149-170.Erişim adresi:http://static.dergipark.org.tr/articledownload/0d76/6b1d/1e30/imp-JA94VJ52SK-0.pdf?

Erdut, T. (2011). Toplumsal cinsiyet bakımından evde çalışma. Calışma ve Toplum Dergisi, 2, 55-82. Erişim adresi: http://www.acarindex.com/dosyalar/makale/acarindex-1423873968.pdf

Ertürk, Y. (1996). Alternatif kalkınma stratejileri: Toplumsal cinsiyet, kadın ve eşitlik, ODTÜ Gelişme Dergisi, 23 (3), 341-356.

Gökkaya, V. B. (2018). Toplumsal cinsiyet algısına ekonomik ve sosyolojik bir bakış. İçinde Y. Kubar ve H. Karakaya (Edt), Kalkinmann önündeki engel toplumsal cinsiyet, kadnn ve ekonomi(ss. 219-270). Ankara: İlksan Matbaas1.

Gül, H.,\& Beyşenova, A. (2018). Kadınların kariyer engelleri ile örgütsel bağll1ıkları arasındaki ilişkiler: Kırgızistan'daki hizmet sektörü üzerine bir araştırma. MANAS Sosyal Araştırmalar Dergisi, 7 (4).

Gürses, D. (2009). İnsani gelişme ve Türkiye. Balikesir University Journal of Social Sciences Institute, 12(21). 339-350.

Güzel, S. (2001). Kadın yoksulluğu ile mücadelede Dünya Bankası ve mikro kredi uygulaması: Türkiye açısından bir değerlendirme, Gender İqtisadiyyati, 8 , 79-96.

Harris, J. M. (2000). Basic principles of sustainable development: Global Development and Environment Institute Tufts University, 00-04.

Hoşgör, A. (2011). Kalkınma ve Kırsal Kadının Değişen Toplumsal Konumu: Birkaç Arpa Boyu...21. Yüzyıla Girerken Türkiye'de feminist çalışmalar. İçinde Sancar. S. (Edt), Kalkınma ve kırsal kadınm değı̧sen toplumsal konumu: Türkiye deneyimi üzerinden karadeniz bölgesindeki iki vakann analizi, (cilt 1, ss. 219-224). İstanbul: Koç Üniversitesi Yayınları.

ILO Katılımcı Toplumsal Cinsiyet Denetimi, Uluslararası Çalışma Örgütü. Erişim adresi: http://www.ilo.org/ankara/publications/WCMS_701388/lang--tr/index.htm.

İşler, R., ve Şentürk, C. (2019). Tarihsel açıdan uluslararası kurum/kuruluşlarda "ekonomik kalkınma" ve "kadın" ilişkisi üzerine bir değerlendirme. Mehmet Akif Ersoy Üniversitesi Sosyal Bilimler Enstitüsü Dergisi, 9(22), 375-388. doi: $10.20875 /$ makusobed.369435

Kabeer, N. (1994). Reversed realities: Gender hierarchies in development thought. London: Verso, 40-69.

Kabeer, N. (2003). Gender mainstreaming in poverty eradication and millennium development goals: A bandbook for policymakersand other stakeholders. Canada: International Development Research Centre.

Kadın Komitesi Hak- İş. (2017). Eğgitim Modülü Cinsiyet Eşitliği: Fıtratta Farklılık Haklarda Eşitlik, Ankara: Uçan Matbaa.

Kalaycı, E. (2019). Sosyal hizmet bakış açısıyla toplumsal cinsiyet eşitliği ve sürdürülebilir kalkınmanın değerlendirilmesi. Journal of International Social Research, 12(66).

Karaçay, H., , Zülfikar, B., Ş., ve Aydın, D. G. (2014). Pos- neoliberal kalkınma paradigmasında kalkınmada kadın ve güçlenme alg1sı: Dünya Bankası örneği. Afyon Kocatepe Üniversitesi İktisadi ve İdari Bilimler Fakültesi Dergisi, 16(2), $15-31$.

Koray, M. (2011). Avrupa Birliği ve Türkiye'de "cinsiyet” eșitliği politikaları: Sol-Feminist Bir Eleștiri. Cahısma ve Toplum Dergisi, 29, 13-53. Erişim adresi: http://calismatoplum.org/sayi29/koray.pdf

Makal, A. (2001). Türkiye'de 1950-1965 döneminde ücretli kadın emeğine ilişkin gelişmeler. Ankara Üniversitesi SBF Dergisi, 56, 117-155.

MClean, M. (2000). Alternative approaches to women and development: theoretical perspectives on gender and development. Ottawa: IDRC Books.

Onaran, Ö. (2000). Türkiye'de yapısal uyum sürecinde emek piyasasının esnekliği. Toplum ve Bilim, 86, 94-21.

Örümcü, A. N. (2015). Girişimci Kadınların Başarı ve Güçlenme Öykülerinin Toplumsal Cinsiyet Analizi: Batı Akdeniz Örneği (Yüksek Lisans Tezi). Süleyman Demirel Üniversitesi Sosyal Bilimler Enstitüsü, Isparta.

Özar, Ş. (2012). Geçmişten günümüze Türkiye'de kadın emeği. İçinde A. Makal ve G. Toksöz (Edt.), Türkiye'de 1980 sonrası dönemde kadın emeği ve istihdam politkalar: Kadın hareketi, sendikalar, devlet ve işveren kuruluşlar (ss.223-255). Ankara: İmge Yayınevi.

Özyol, A. İ. (2013). Sürdürülebilir yeşil kalkınma ve kadın. Fe Dergi, 5 (2), 134-138. Erişim adresi: https://cins.ankara.edu.tr/10_15.pdf

Parpart, J. L. (2014). Exploring the transformative potential of gender mainstreaming in international development institutions. Journal of international Development, 26(3), 382-395.

Rowlands, J. (1997). Questioning empowerment:working with women in Honduras.UK : Oxfam Print Unit.

Rathgeber, E., M. (1989). WID, WAD, GAD: Trends in research and practice. International Development Research Centre Ottowa, 5. 
Sachs, W. (Eds.) (2010). The development dictionary (2. Edition). London \& New York: Zed Books. Erişim adresi:https://shifter-magazine.com/wp-content/uploads/2015/09/wolfgang-sachs-the-developmentdictionary-n-a-guide-to-knowledge-as-power-2nd-ed-2010-1.pdf

Sancar, S. (2018). Siyasal kararlara katıllmda toplumsal cinsiyet esittiği.Ankara: Ceid Yayınları.

Şenses, F. (2004). Neoliberal küreselleşme kalkınma için bir firsat mı, engel mi? Kalkınma ve Küreselleşme, 1-27. Erişim adresi:http://erc.metu.edu.tr/en/system/files/menu/series04/0409.pdf

Stromquist, N. P. (1995). Women, education and empowerment: Pathways towards autonomy, C. M. Afionuev (Eds.), The Theoretical and Practical Bases for Empowerment. Hamburg: UNESCO Institute for Education, 13-27.

The World Bank. (1995). The world bank participation sourcebook. Washington: World Bank Environment Department Papers.

T.C. Başbakanlık Kadının Statüsü ve Sorunları Genel Müdürlügü. (2000). Kadın istihdamı için yeni perspektifler ve kadın isgücüne mubtemel talep. Ankara: Cem Web Ofset.

Tolay, E., Sürgevil, O. Ve Topoyan, M. (2012). Akademik çalışma ortamında yapısal ve psikolojik güçlendirmenin duygusal bağlılık ve iş doyumu üzerindeki etkileri. Ege Akademik Bakıss, 12 (4). 449-465.

Taş, U. ve Yenilmez, F. (2008). Türkiye'de eğitimin kalkınma üzerindeki rolü ve eğitim yatırımlarının geri dönüş oran1. Eskişehir Osmangazi Üniversitesi Sosyal Bilimler Dergisi, 9(1), 155-186.

Toksöz, G. (2011). Kalkınmada kadın emeği. İstanbul: Varlık Yayınları.

Uluslararası Kadın Sağlık Örgütü. (2001). Pekin+ 5: Birleşmis Milletler'de kadınm insan haklar ve Türkiye'nin taabbütleri. Ankara: Kadının İnsan Hakları Projesi (KİHP) - Yeni Çözümler Vakfı İrtibat Bürosu. Erişim adresi: http://www.ceidizleme.org/ekutuphaneresim/dosya/219_1.pdf

UN Women, TheWomen's Empowerment Principles. Erişim adresi: https://www.unglobalcompact.org/takeaction/action/womens-principles.

Walby, S. (2005). Gender mainstreaming: Productive tensions in theory and practice. Oxford Unv. Press 12(3), 1-25. Doi: $10.93 / \mathrm{sp} /$ jxi018

World Bank. (2000). Attacking Poverty: World Development Report 2000/01. Erişim adresi: http:/ / documents.worldbank.org/curated/en/230351468332946759/World-development-report-2000-2001attacking-poverty

Yavuz, G. ve Serdaroğlu, U. (2010). Kalkınma ve kadın (veya toplumsal cinsiyet) ilişkilendirilişinin değişimindeki kavşaklar. Ekonomik Yaklașım, 19, 121-164. doi: 10.5455/ey.10651

Yıldız, N. (2005). G-20 Küresel sorunları çözecek bir aktör müdür? Hak-Iș Uluslararası Emek ve Toplum Dergisi, 4(9).

Yücel, Y. (2016). Toplumsal cinsiyet tartışmaları. İçinde Saygılligil, F. (Edt), Ekonomik kalkınma ve toplumsal cinsiyet, (ss 86-102). Ankara: Dipnot Yayınlar1.

Zihnioğlu, Ö. (2013). Kadının güçlendirilmesi ve eğitim. T.C. İstanbul Kültür Üniversitesi Küresel Eğilimler Serisi Calıs̆ma Kâğıdı, 1(1). Erişim adresi: https://www.files.ethz.ch/isn/159593/KE-1_2013_Zihnioglu.pdf

\section{EXTENDED ABSTRACT}

Development is a dynamic, multi-dimensional concept that varies considerably. The concept of development, which has been used more and more since the 1930s, was primarily regarded as economic growth, and even synonymous with modernization. Thus, development of any country was claimed to be directly proportional to the level of technologic development, increase in national income and other economic indicators, hence it was unarguably accepted that figures reflect the development as well. In 1970s, in some countries, despite economic growth some problems such as political instability and increase in unemployment caused by in equality appeared. In 1980s, also with the influence of globalization, the process of structural adjustment policies started under the supervision of WB and IMF. In this period, most of the societies, especially women, were exposed to poverty and unemployment, and made them accept both migration from rural are as to urban and un insured working conditions there. Using low-wage labor force, especially in the export sector, caused a remarkable increase in the number of female employees in the labor market. In this process, serious problems such as income inequality and unemployment occurred all around the world, and ideas that economic growth alone does not provide a solution for development began to emerge. It was emphasized in the 1990 Human Development Report that the eventual aim of development should be based on human achievements, freedoms and capabilities. Therefore, since then, it has turned out that income - oriented understanding alone is not enough for development, and the importance of the human factor has come under discussion. In the years of 2000, there has been a general consensus that development includes the concepts such as improvements, innovations and changes in a positive way based on living conditions of people. Today, there is a strong belief that, for a country to be a developed country, it is not enough to be economically developed, it has to be developed in terms of social, political and human rights. When looked at from a historical perspective, in development policies, women were not brought up as much as necessary until 1970. Even women, in the reports on women, in implementation policies, were not seen as economic actors but as tools for the purpose. For this reason, the focus was on their productivity, and studies were conducted in 
that way. The concept of empowerment, like development, has a complex and dynamic structure, and it conveys different meanings in cultural and political contexts, which come out as different perceptions according to various regions and countries.

Nevertheless, strengthening, in general, represents the quality of lifestyle, dignity and well-being of all men and women. In this respect, while the concepts of both development and empowerment may already lead to controversy alone, it is difficult to achieve a systematic result in 'women empowerment in development'.

Being empowered, taking decision, implementing decision, exercising the will and preference are, of course, related to power. This situation caused some feminists to make an alternative definition in order to discuss this concept in detail and pursue the issue from the perspective of gender. According to them, the concept 'being empowered' emerged as a reaction to lack of women in development, and isolated them as a separate group. Because, in order to be empowered, another person, more precisely, a strong actor must be transferred to the other side. In other words, the existence of a power is possible only with the acceptance of the phenomenon that one side is less powerful. Consequently, theevaluationaboutwomenempowermentwasmadebythosewhohavecontrolovertheresoucesandwealth, and who were in a position to make decisions about politics and financial issues, which caused considerable discussions in the phase of measurement and evaluation of empowerment.

In recent years, in order to establish gender equality in development policies, there have been more interventions regarding women empowerment and it has been brought about as an important issue that must be taken into consideration. Gender is the understanding that without discriminate people according to their sexes, people must have the freedom to enjoy their rights or the rights that they must have independent of the strict roles of gender, and benefit from every opportunity possible. In fact, women empowerment is both the process and the result. It has been defined by the World Bank that strengthening women is the key to all programs. However, due to the fact that, without totally established consciousness about gender, policies regarding empowerment of women were implemented, and that the programsprioritized economy, for many years, women have worked under hard conditions and the work they did required more labor, which paved the way for women to lose power both physically and spiritually. Thus, the results of the efforts to empower women in international development policies have caused controversy in terms of gender equality.

In general, it has been observed that, in national and international policies, women's participation in the economy takes priority under the heading of empowerment women. Although it is not denied that the woman who took her economic freedom has started to change primarily herself and her environment, even the society in a positive way, every step taken with the understanding that the woman in the labor market is a strongwoman has made the lives of women more difficult with the effect of neo-liberal policies. Because women, including themselves, prioritize the works such as motherhood, nursing, housework, which are imposed by the gender roles in the existing patriarchal system, and they are concentrated in jobs with more flexible working hours in the labor market. As a result, more and more women have started to work in uninsured, union-free and dangerous jobs. In addition, women made great effort to prove themselves in this established system, and every move they made to survive and succeed caused more material and moral effort. However, in reality, women empowerment can be realized not by someone else, but by internal self-domination, raising consciousness, individual change, awareness of inequalities and taking action. 